\title{
Vol'nočasové aktivity v Slovenskej a Českej republike: sú faktory, ktoré ich ovplyvňujú, národne špecifické? ${ }^{1}$
}

\author{
Ivan Chorvát ${ }^{2}-$ Jiř́ Šafr ${ }^{3}$ \\ Filozofická fakulta Univerzity Mateja Bela v Banskej Bystrici \\ Sociologický ústav AV ČR, v. v. i., Praha
}

\begin{abstract}
Leisure Activities in Slovakia and the Czech Republic: Are the Factors that Influence them Nationally Specific? This article focuses on the factors that influence leisure time in Slovakia and the Czech Republic by using a dataset from coordinated surveys on leisure time carried out in 2016 (Slovakia) and 2011 (Czech Republic). We show the internal structure of leisure activities determined by the social logic of cultural taste. Amongst more than 20 activities examined, we identify three basic spheres-active lifestyle/highbrow culture (forming cultural capital), out-of-home entertainment/consumption of new media and domesticity/family life. The main goal is to identify the factors differentiating these elementary lifestyles. We test hypotheses on the divergent influences of age, education and residence size on leisure activities in the two countries. The analysis confirmed the hypotheses in only two areas of leisure-active lifestyle/highbrow culture and partly in out-of-home entertainment/new media consumption. The results show that more culturally demanding forms of leisure are determined not only by individual factors but also to some extent by structural differences in settlement arrangements and broader historical and cultural circumstances. Sociológia 2021, Vol. 53 (No. 2: 147-179)

https://doi.org/10.31577/sociologia.2021.53.2.6
\end{abstract}

Kl'účové slová: Leisure time determinants; structure of leisure activities; cultural capital; Slovakia; Czechia

\section{Úvod}

Napriek množstvu zahraničných štúdií o trávení vol'ného času existuje len málo prác, ktoré by sa venovali porovnávaniu dvoch či viacerých spoločností (napr. Birkelund - Lemel 2013; Chan 2010; Coulangeon 2005; Coulangeon - Roharik 2005; Katz-Gerro 2002, 2006; Lemel - Katz-Gerro 2015). Navyše sa takmer univerzálne venujú len určitému výseku vol’nočasových aktivít, a skoro výhradne iba kultúrnej participácii a kultúrnej spotrebe. Spoločné majú aj to, že väčšinou pracujú s dátami z medzinárodných výskumných programov (napr. ISSP, Eurobarometer), ktoré disponujú iba obmedzeným množstvom sledovaných indikátorov, a nie s národnými výskumami s širšou paletou vol'nočasových

\footnotetext{
1 Práca druhého autora na tomto článku bola podporená projektom GAČR „Kulturní zdroje rodiny: vliv na gramotnost, akumulaci kulturního kapitálu dítěte a na výsledky ve vzdělávání“ č. GA20-12023S, harmonizovaný dátový súbor bol využitý z výskumnej infraštruktúry ČSDA podporovanej MŠMT v projekte CSDA (reg. č. LM2018135), jeho vytvorenie sa uskutočnilo v rámci projektu CSDA Research (MŠMT ČR, reg. č. CZ.02.1.01/0.0/0.0/16_013/0001796). Výsledky sú prezentované ako súčast' výskumného programu Akademie věd ČR Strategie AV21/14.

2 Korešpondencia: doc. Mgr. Ivan Chorvát, M.A., CSc., Univerzita Mateja Bela, Filozofická fakulta, Katedra sociálnych štúdií a etnológie, Tajovského 40, 97401 Banská Bystrica, Slovenská republika. E-mail: ivan.chorvat@umb.sk

${ }^{3}$ Korešpondencia: PhDr. Jiří Šafr, Ph.D., Sociologický ústav AV ČR, v. v. i., Jilská 1, 11000 Praha 1, Česká republika. Email: jiri.safr@soc.cas.cz
}

Sociológia 53, 2021, č. 2 
aktivít. Tieto výskumy zvyčajne sledujú iba aktivity späté s vysokou (legitímnou) kultúrou. Navyše pri komparácii viacerých krajín ani nie je možné detailnejšie vysvetlit' príčiny odlišností $\mathrm{v}$ spôsobe trávenia vol'ného času vyplývajúce zo štrukturálnych, inštitucionálnych a sociokultúrnych rozdielov a odlišností historických trajektórií ${ }^{4}$. Naša štúdia má ambíciu prekonat tieto obmedzenia. Na rozdiel od väčšiny ostatných sa zameriava, pokial' ide o kultúrny vkus, na širokú paletu vyše dvadsiatich vol'nočasových aktivít s využitím národných vzájomne koordinovaných výskumov priamo zameraných na trávenie vol’ného času. Navyše podáva vysvetl'ujúci kontext spoločenského vývoja a štrukturálnych rozdielov $\mathrm{v}$ obidvoch spoločnostiach $\mathrm{v}$ posledných troch desat'ročiach.

Hoci téma vol'ného času bola v 60 . až 80 . rokoch 20 . storočia v československej sociológii pomerne frekventovaná, po roku 1990 sa výskum orientoval skôr iným smerom a k obnoveniu záujmu o životný štýl a kultúrnu spotrebu dochádza až zhruba v poslednej dekáde, najmä pokial' ide o väzbu kultúrnej spotreby na triedne postavenie (Šafr 2008; 2012; Bunčák et al. 2019). Výsledky týchto výskumov ukazujú, že kultúrne praktiky, presnejšie povedané kultúrne náročnejšie aktivity vol'ného času v českej i slovenskej spoločnosti sú podmienené triednou príslušnost'ou a že sa $\mathrm{v}$ nich uplatňuje model triednej homológie. Popri platnosti tohto modelu je však možné u príslušníkov vyšších sociálnych tried zaznamenat' fenomén tzv. kultúrnej všežravosti, t. j. okrem nadpriemernej miery aktivít patriacich do vyššej kultúry sa pomerne často venujú aj aktivitám, ktoré bývajú zaradené do oblasti nízkej resp. masovej kultúry. Pokial' však ide o širší kontext spôsobov trávenia vol'ného času, nezostáva než konštatovat', že až donedávna (pozri Chorvát - Šafr eds. 2019) chýbalo systematickejšie porovnanie našich krajín, a ak nepočítame krátke exkurzie na túto tému v Šafr - Patočková (2010) a Chorvát (2011), najkomplexnejšie porovnanie rozdielov $\mathrm{v}$ životnom štýle a jeho determinantov medzi našimi krajinami predstavujú viac ako polstoročia staré výsledky z výskumu československej spoločnosti z roku 1967 (Linhart 1969; Roško et al. 1969).

Ciel'om predkladanej štúdie je preskúmat' prípadnú existenciu rozdielov týkajúcich sa vplyvu rôznych faktorov na spôsoby trávenia vol’ného času na Slovensku a v Česku. V úvodnej časti sa budeme venovat' niektorým univerzálnejším tendenciám ovplyvňujúcim vol’ný čas v súčasných vyspelých spoločnostiach. Následne sa zameriame na niektoré štrukturálne rozdiely medzi českou a slovenskou spoločnost'ou, ktoré majú potenciál ovplyvňovat' vol'nočasové aktivity. V empirickej časti najprv identifikujeme štruktúru trávenia vol'ného času a overujeme jej platnost' pre obe krajiny. V hlavnej časti

${ }^{4}$ Výnimku predstavuje komparácia Izraela a Francúzska (Lemel - Katz-Gerro 2015). 
sa potom venujeme analýze determinantov trávenia vol’ného času, pričom sa zameriame na odlišné pôsobenie socio-demograficko-geografických vplyvov vyplývajúcich z odlišných štrukturálnych podmienok našich krajín.

\section{Vol'ný čas v 21. storočí a faktory ovplyvňujúce spôsoby jeho trávenia}

V moderných spoločnostiach je vol’ný čas chápaný ako „sféra individuálnej vol'by, vktorej sa rozhodujeme slobodne, na základe svojich preferencií a prianí“ (Chorvát 2019a: 17). V súčasnosti viac než kedykol’vek v minulosti platí, že l'udia z rôznych sociálnych vrstiev majú viac času na svoj vol'ný čas a majú možnost' ovel'a väčšieho výberu zo širokej škály pestrých vol'nočasových aktivít, vrátane zábavy, prežívania zážitkov či naplńania túžob. Tieto možnosti v druhej dekáde 21 . storočia stále viac umocňuje presun mnohých oblastí trávenia vol'ného času do prostredia internetu. Neisté formy zamestnania, predížená doba vzdelávania, rozporuplné pravidlá ako aj neustále sa meniace návody na to, ako dosiahnut životný úspech a zabezpečenie spôsobujú, že „sféra vol’ného času sa stáva pre mnohých najspol’ahlivejším zdrojom identity, pevným oporným bodom, prostredníctvom ktorého si budujú zmysluplnost' a konzistenciu svojho života“ Chorvát 2019a: 37). Avšak to, čo vyzerá na prvý pohl'ad ako slobodná vol'ba (trend individualizácie), v skutočnosti až tak úplne nezávislé nie je, lebo limitmi nášho spôsobu trávenia vol’ného času nie sú iba zjavné skutočnosti, ako zdravotný stav či finančné prostriedky, ale aj sociálne prostredie či historicky podmienené a zdiel'ané skúsenosti.

Jednotlivé faktory, ktoré majú vplyv na trávenie vol’ného času, je možné rozdelit' do dvoch základných kategórií. (1) Individuálne faktory, ako je pohlavie, vek resp. fáza životného cyklu, vzdelanie, sociálne postavenie (profesia), rodinné zázemie. Ak vynecháme rýdzo psychologicko-osobnostné prediktory, môžeme medzi ne zahrnút' aj niektoré limitujúce okolnosti ako zdravotný stav, množstvo vol'ného času resp. miera zapojenia do pracovného procesu a predovšetkým dostupnost' (finančná a priestorová) vol’nočasových aktivít, na ktoré poukázali doterajšie výskumy (napr. Lemel - Katz-Gerro 2015; Gruenberg 1983; Šafr 2012; Taylor 2016). Úplne samostatným faktorom je socializácia $\mathrm{v}$ detstve prebiehajúca primárne $\mathrm{v}$ rodine. Do značnej miery totiž dochádza $\mathrm{k}$ medzigeneračnému prenosu životného štýlu $\mathrm{z}$ rodičov na deti - $\mathrm{k}$ utváraniu habitu, ktorý je výsledkom vzájomného pôsobenia socializačných praktík rodičov a triedno-štruktúrnej pozície. Záleží ale na konkrétnej oblasti vol'ného času, vplyv kultúrno-interakčnej socializácie aj sociálneho statusu možno zaznamenat' najmä pri aktivitách spojených s kultúrnou spotrebou a športom, a tiež pri zábave mimo domova a sledovaní televízie, kde je ale vplyv statusu rodiny slabý (Patočková et al. 2012). (2) Rámcované - kontextuálne faktory dané spoločnost'ou a kultúrou, predovšetkým existujúce inštitucionálne 
prostredie, verejné politiky ale aj hodnoty a tradície danej kultúry. Do takejto kategórie možno tiež zaradit' efekty spojené s generačne zdiel'anou skúsenost’ou danou príslušnost'ou $\mathrm{k}$ vekovej kohorte socializovanej v určitom období, pretože hodnoty a základné orientácie človeka vo svete sa utvárajú v tzv. formatívnom veku, v období dospievania. Toto obdobie sa môže vyznačovat' vonkajšími kultúrnymi, politickými a spoločenskými podmienkami, ktoré sú zdiel'ané a internalizované príslušníkmi danej kohorty. Habitus - individuálne dispozície nazerania na svet a konania v ňom, ktorý je v Bourdieuho chápaní internalizovaný $\mathrm{v}$ detstve a preto primárne triedne podmienený (Bourdieu 1984) a ktorý do značnej miery predeterminuje spôsoby trávenia vol'ného času $\mathrm{v}$ neskorej dospelosti, sa neutvára $\mathrm{v}$ akomsi časovom vákuu, ale v konkrétnom historicko-kultúrnom rámci.

Pochopitel'ne, že faktory ovplyvňujúce trávenie vol'ného času závisia aj od typu vol'nočasovej činnosti. Bez ohl'adu na konkrétnu sféru trávenia vol'ného času však môžeme na základe empirických výskumov v (nielen) komparatívnej perspektíve konštatovat', že hlavnými sa ukazujú byt' vek a vzdelanie. Menší vplyv majú rozdiely v životnej úrovni, pohlavie a miesto bydliska (Lemel Katz-Gerro 2015). Vzdelanie však zohráva menšiu rolu v tých krajinách, ktoré sa vyznačujú relatívne vysokým zastúpením vysokoškolsky vzdelanej populácie (Falk - Katz-Gerro 2016), čo sa však súčasnej českej ani slovenskej spoločnosti ešte netýka (ako si ukážeme d’alej).

Celkovo tak môžeme očakávat', že pri determinácii spôsobov trávenia vol'ného času v našich krajinách sa uplatňujú vyššie uvedené faktory, a že tak stále platia pozorovania z výskumu československej spoločnosti 60. rokov minulého storočia (Linhart 1969) o väčšom význame socializačných faktorov (kam zarad’ujeme i vzdelanie a rodinný pôvod) než situačných faktorov (príjmových, mocenských atd'.).

\section{Rozdiely medzi slovenskou a českou spoločnost'ou s potenciálom odlišného vplyvu na trávenie vol’ného času}

Trávenie vol'ného času sa v krajinách na podobnej ekonomicko-sociálnej úrovni môže v niektorých ohl'adoch odlišovat', lebo platí, že prevažujúce vzorce vol'ného času v spoločnosti ovplyvňuje i jej predchádzajúci spoločenský vývoj, ako aj kultúrne, geografické a d'alšie podmienky a okolnosti. V tejto časti sa vel'mi stručne zameriame iba na tie štrukturálne faktory, ktoré by mohli mat' vplyv na odlišné spôsoby trávenia volného času na Slovensku a v Česku'.

Všeobecne tieto štrukturálne rozdiely vyplývajú $\mathrm{z}$ rozdielneho priebehu modernizácie oboch spoločností a obdobia, v ktorom prebiehala (Musil 1993).

\footnotetext{
5 Ovel’a detailnejšiu analýzu rozdielov medzi českou a slovenskou spoločnost’ou je možné nájst' v (Chorvát 2019b).
} 
V českej spoločnosti sa realizovala postupnejšie a dlhodobejšie prevažne pred obdobím socialistického Československa, kým na Slovensku sa proces modernizácie väčšinovo uskutočňoval až v období socializmu, v podobe historicky oneskorenej a štátnou intervenciou vyvolanej industrializácie a urbanizácie, ktorá sa udiala urýchlene a neorganicky v priebehu šest'desiatych až osemdesiatych rokov 20. storočia (Gajdoš - Pašiak 1995).

A tak už pred viac ako polstoročím uskutočnený výskum československej spoločnosti identifikoval medzi najvýznamnejšími modernizačnými faktormi ovplyvňujúcimi spôsob trávenia vol’ného času a životného štýlu vzdelanie a vel'kost' lokality. Rozdiely boli dôsledkom odlišného stupňa vývoja urbanizácie a tým aj lepšej vybavenosti českých sídel službami vrátane zariadení slúžiacich na vol’nočasové aktivity. Ďalšími dôležitými faktormi boli odlišné zloženie rodín (vyšší výskyt viacdetných rodín na Slovensku) a predovšetkým odlišná mentalita obyvatel'ov podmienená najmä rozdielnou profesijnou/odvetvovou štruktúrou. Jej prejavom bolo $\mathrm{v}$ tej dobe na Slovensku omnoho silnejšie zastúpenie rol'níctva, ale aj fakt, že sa prevažujúca rol'nícka mentalita prejavovala aj v životnom spôsobe l'udí nerol'níckych profesií, napríklad vnímaním sociálnej stability realizovanej prostredníctvom vlastníctva rodinného domu a s tým spätej náplni vol'ného času (Roško et al. 1969; porovnaj tiež Radičová 1989). Preto sa teraz konkrétnejšie zameriame na niektoré vybrané aspekty štrukturálnych rozdielov.

Čo sa týka kultúrnych rozdielov, historicky sa výraznejšie prejavovali rozdiely $\mathrm{v}$ dôraze na rodinu a v miere religiozity. Stručné povedané, pre obyvatel'ov Slovenska je príznačnejšia väčšia súdržnost' širšej rodiny, stabilnejšie a tradičnejšie demografické správanie, nižší stupeň sekularizácie a významnejšia rola susedstva a komunitných väzieb (Chorvát 2019b). Tieto rozdiely vyplývajúce $z$ rozdielneho historického vývoja i odlišného priebehu a charakteru modernizačných procesov sa $\mathrm{v}$ oboch spoločnostiach prejavujú aj $\mathrm{v}$ hodnotových preferenciách. Okrem spoločenských inovácií spätých väčšinou s nastupujúcou generáciou, ale aj s historickými mílnikmi ako bola napríklad tzv. nežná revolúcia v roku 1989, dochádza taktiež $\mathrm{k}$ prenosu hodnôt medzi generáciami odovzdávanými predovšetkým $\mathrm{v}$ procese primárnej socializácie. V dôsledku toho sme $\mathrm{v}$ jednotlivých generáciách svedkami akýchsi sedimentov rôznych spoločenských noriem a hodnôt.

Nesmieme zabudnút' ani na materiálne podmienky života a životnú úroven̆, lebo tiež významne ovplyvňujú dostupnost' mnohých vol’nočasových aktivít. Po rozdelení spoločného štátu boli ekonomické ukazovatele podstatne priaznivejšie pre Českú republiku, najmä priemerné mzdy Čechov rástli rýchlejšie. Až po roku 2000 začalo Slovensko tento náskok postupne st'ahovat', stále však v tejto oblasti za svojim susedom zaostáva. Navyše platí, že mzdové rozdiely sú na Slovensku regionálne ovel’a výraznejšie a dá sa predpokladat', že

Sociológia 53, 2021, č. 2 
aj rozdiely v životnej úrovni medzi českým mestom a vidiekom sú nižšie než na Slovensku (bližšie pozri Chorvát 2019b).

Dôležitú rolu tiež zohrávajú trendy v demografickej a vzdelanostnej skladbe obyvatel'stva oboch krajín. Ich vekové zloženie je vdospelých vekových kohortách v zásade podobné, s mierne vyšším zastúpením mladých l'udí do 30 rokov na Slovensku a na druhej strane s vyšším podielom l'udí nad 60 rokov v Českej republike. Čo sa týka vzdelania, azda najdôležitejšieho faktora vol'nočasovej diferenciácie, vzdelanostná skladba $\mathrm{v}$ obidvoch našich spoločnostiach $\mathrm{v}$ poslednom viac ako štvrt'storočí prešla výraznou premenou, najmä vd’aka bezprecedentnému nárastu počtu vysokých škôl ako aj ich zvýšenej regionálnej dostupnosti. V tabul'ke č. 1 je možné zretel'ne vidiet' kontinuálny trend klesajúceho počtu l'udí so základným vzdelaním a rastu počtu vysokoškolákov v mladších vekových kategóriách. Najvýraznejší rozdiel môžeme pozorovat' pri základnom vzdelaní v najstaršej vekovej kategórii, ktorá bola narodená pred koncom 2. svetovej vojny, $\mathrm{s}$ vyšším zastúpením tohto typu vzdelania na Slovensku. Z dát $\mathrm{z}$ posledného sč́tania obyvatel'stva $\mathrm{v}$ oboch krajinách v roku 2011 vyplýva aj možno pomerne prekvapujúci poznatok o celkovo vyššom zastúpení l'udí s vysokoškolským vzdelaním na Slovensku, ktorý sa výraznejšie prejavuje najmä v mladších vekových kohortách, čo svedčí o dynamickejšej vzdelanostnej expanzii po roku 1989 práve v Slovenskej republike.

Tabul'ka č. 1: Vzdelanostná úroveň v populácii od 25 rokov vo vekových kategóriách, SR a ČR 2011

\begin{tabular}{|c|c|c|c|c|c|c|c|c|c|c|c|c|c|c|c|c|c|c|c|c|}
\hline & \multicolumn{2}{|c|}{$25-29$} & \multicolumn{2}{|c|}{$30-34$} & \multicolumn{2}{|c|}{$35-39$} & \multicolumn{2}{|c|}{$40-44$} & \multicolumn{2}{|c|}{$45-49$} & \multicolumn{2}{|c|}{$50-54$} & \multicolumn{2}{|c|}{$55-59$} & \multicolumn{2}{|c|}{$60-64$} & \multicolumn{2}{|c|}{$65+$} & \multicolumn{2}{|c|}{ Celkom } \\
\hline & SR & ČR & SR & ČR & SR & ČR & SR & ČR & SR & ČR & SR & ČR & SR & ČR & SR & ČR & SR & ČR & SR & ČR \\
\hline bez vzdelania & 0 & 1 & 0 & 1 & 0 & 1 & 0 & 1 & 0 & 1 & 0 & 1 & 0 & 1 & 0 & 1 & 0 & 1 & 0 & 1 \\
\hline ZŠ & 7 & 7 & 6 & 6 & 6 & 6 & 7 & 6 & 8 & 8 & 12 & 11 & 17 & 17 & 17 & 16 & 39 & 30 & 15 & 14 \\
\hline VY & 18 & 26 & 25 & 32 & 35 & 41 & 36 & 41 & 37 & 40 & 39 & 44 & 36 & 43 & 36 & 43 & 28 & 36 & 31 & 38 \\
\hline SŠ & 43 & 41 & 42 & 41 & 38 & 37 & 39 & 37 & 37 & 36 & 33 & 30 & 31 & 28 & 34 & 30 & 23 & 24 & 35 & 33 \\
\hline VŠ & 32 & 25 & 27 & 20 & 21 & 15 & 18 & 15 & 17 & 16 & 16 & 15 & 15 & 12 & 13 & 10 & 10 & 9 & 19 & 14 \\
\hline Celkom \% & 100 & 100 & 100 & 100 & 100 & 100 & 100 & 100 & 100 & 100 & 100 & 100 & 100 & 100 & 100 & 100 & 100 & 100 & 100 & 100 \\
\hline Celkom \% veku & 11 & 9 & 12 & 11 & 11 & 11 & 9 & 9 & 10 & 9 & 10 & 9 & 10 & 10 & 8 & 10 & 18 & 22 & 100 & 100 \\
\hline
\end{tabular}

Zdroj: Sčítanie obyvatel'ov, domov a bytov 2011 SR, Sčítání lidu, domů a bytů 2011 ČR (vlastné výpočty)

Vel'mi dôležitým faktorom ovplyvňujúcim trávenie vol’ného času je i to, aké majú l'udia možnosti výberu vol'nočasových aktivít, jednak zhl’adiska možností ich dosiahnutia ako aj variability miestne ponúkaných možností. Táto dostupnost' súvisí s rozvinutost'ou infraštruktúry zariadení pre vol'ný čas a jej dostupnosti najmä $\mathrm{v}$ regionálnych centrách. $\mathrm{V}$ tomto ohl'ade sa naše krajiny líšia azda najviac. Tu sa prejavuje ešte stále isté pretrvávanie modernizačného 
deficitu slovenských sídel oproti českým a zaostávanie v zníženej dostupnosti a v menšej hustote siete zariadení určených pre vol'nočasové aktivity, či už v oblasti kultúry, športu alebo rekreácie. Predpokladáme, že táto znížená dostupnost' sa týka najmä vidieckych oblastí a menších sídel. Vy̌šśí podiel vidieckeho obyvatel'stva a na európske pomery nízka urbanizovanost' Slovenska sú všeobecne známou skutočnost'ou. Kým v Českej republike žije v mestách okolo $63 \%$ obyvatel'stva (ČSÚ 2003), na Slovensku je to len niečo viac než polovica (54\% v roku 2011, pozri Gajdoš 2015: 186) ${ }^{6}$, čo ešte stále zarad'uje Slovensko medzi krajiny s najvyššou mierou vidieckej populácie v Európe. Na vyššiu rurálnost' Slovenska ukazuje tiež miera urbanizácie oblasti zohl'adňujúca aj hustotu zaluudnenia v okolí obce (Degree of Urbanisation): v rurálnych - riedko obývaných oblastiach $\left(<100\right.$ obyvatel'ov $\left./ \mathrm{km}^{2}\right)$ žije v ČR $37 \%$ a na Slovensku $43 \%$, kým v mestských aglomeráciách - husto obývaných oblastiach $\left(>500\right.$ obyvatel'ov $\left./ \mathrm{km}^{2}\right)$ žije v ČR $30 \%$, ale na Slovensku len $21 \%$ obyvatel'stva (Eurostat 2016, vlastné výpočty).

Vel'kost' sídel a ich rurálnost' s ohl'adom na populačnú hustotu je však len hrubým pohl'adom na geografickú podmienenost' možností trávenia vol'ného času. Z hl’adiska tzv. geografickej štruktúry príležitostí sú dôležitejšie jednak dostupnost' mestských centier poskytujúcich zázemie pre náročnejšie aktivity vol'ného času (vykonávaných mimo domova) a tiež sociálno-ekonomické vlastnosti danej oblasti či regiónu. Tu je dôležité spomenút' sídelné špecifiká Slovenska, ktoré sú výsledkom zmien v procesoch sídelnej štruktúry od 90. rokov, najmä prehlbovanie medziregionálnych rozdielov a pomerne jasné vydelenie marginálnych, problémových regiónov na Slovensku (Gajdoš Moravanská 2011: 105). Pretrváva infraštruktúrna podrozvinutost' niektorých častí Slovenska, hlavne v súvislosti s dopravnou periférnostou (Džupinová et al. 2008).

Základný poznatok o nerovnomernej štruktúre príležitostí a dostupnosti mestských centier nám nakoniec poskytne aj zbežný pohl'ad na mapu s vyznačenými mestami nad 20000 obyvatel'ov. Ich podiel na celkovom počte obcí je síce podobný ( $v$ ČR 61, na Slovensku 38 takto vel'kých miest), podstatne sa však líšia v geografickom rozmiestnení, ktoré je v Česku ovel'a rovnomernejšie než na Slovensku. Na mape SR je viditel'ná často spomínaná vzdušná línia medzi západoslovenskými Levicami a východoslovenským Popradom, ktorá rozdeluje Slovensko na dve časti, na „bohatý severozápad“ a „chudobný juhovýchod“ (pozri Halás 2008). Južne od spomínanej línie, na pomerne rozsiahlom území približne štvrtiny územia Slovenska, sa nachádzajú

6 Tieto údaje vychádzajú z bežne používanej definície urbanizácie ako podielu žijúcich v obciach nad 5 tisíc obyvatel’ov.

Sociológia 53, 2021, č. 2 
len tri mestá s počtom obyvatel’ov nad 20000 (Lučenec, Rimavská Sobota, Spišská Nová Ves).

Aj preto môžeme v prípade Slovenska hovorit' o priestorovej koncentrácii periférnych regiónov (nielen zhl'adiska dopravnej dostupnosti) v južných častiach stredného Slovenska (približne medzi Levicami a Rožňavou), v severnej, severovýchodnej a východnej časti východného Slovenska a čiastočne aj na severnom okraji stredného Slovenska (Orava). Naproti tomu sú $v$ Českej republike periférne regióny viac rozptýlené a ako celok sa vyznačujú vel'kou variabilitou, $v$ ich prípade môžeme v zásade hovorit' o redšie osídlenom pol’nohospodárskom vidieku. Z hl’adiska potenciálneho vplyvu rezidenčného charakteru územia na správanie obyvatel’ov $\mathrm{v}$ oblasti trávenia vol'ného času je podstatná skutočnost', že v periférnych územiach Česka pravdepodobne žije menši podiel obyvatel'ov než na Slovensku'. Vyššie uvedené poznatky nás vedú ku konštatovaniu, že okrem väčšej nerovnomernosti geografického rozmiestnenia väčších sídel na Slovensku je dôležité pozriet' sa aj na to, aké možnosti trávenia vol’ného času ponúkajú sídla, ktoré by sme mohli označit' ako regionálne centrá. A v tejto súvislosti môžeme konštatovat', že infraštruktúra miest, ktoré sa podobajú nielen vel'kost'ou, ale aj svojím regionálnym významom, je zrejme rozvinutejšia v Českej republike.

Ukazuje sa to napríklad v oblasti kultúry či športu, ktoré bezprostredne súvisia s možnost’ami trávenia vol'ného času mimo domova. Napríklad v roku 2014 sa v českých divadlách odohral trojnásobný počet predstavení než na Slovensku, v roku 2015 v českých kinách sledovalo film takmer trikrát viac divákov (a počet kín bol v Česku viac ako pät’násobný). Podobná situácia je aj v prípade verejných knižníc, ktoré sú dôležitým zázemím pre kultúrne orientované vol'nočasové aktivity aj v menších obciach. V roku 2014 bol ich počet v ČR trojnásobne vyšší. Aj počet múzeí a galérií bol v roku 2014 v Českej republike štvornásobne a počet galérí trojnásobne vyšší a nejakú výstavu či expozíciu v múzeu alebo galérii navštívil v Česku v porovnaní zo Slovenskom štvornásobok návštevníkov, čo sú vo všetkých prípadoch vyššie čísla než by vyplývalo z proporcionálne väčšej rozlohy územia a dvojnásobného počtu obyvatel’ov Česka (Statistická ročenka ČR 2016; Štatistická ročenka SR 2015; NOC 2017).

Menej prehl'adná je situácia pokial' ide o infraštruktúru zázemia pre športové aktivity, lebo ucelené zoznamy športových zariadení nie sú k dispozí-

\footnotetext{
${ }^{7}$ Porovnatel’né údaje tu bohužial' nie sú k dispozícii. Aspoň približne podobné vymedzenie periférií poskytujú štúdie Halása (2008) a Musila s Müllerom (2008) zahŕňajúce pre nás kl’účovú dostupnost' lokálno-regionálnych centier, v ktorých je možné realizovat' vol'nočasové aktivity. Aj pri odlišnom vymedzení periférií, ktoré výrazne podhodnocuje počet periférnych územi v SR, možno konštatovat', že v periférnych územiach Slovenska žije približne 7,6 \% populácie (Halás 2008: 366), zatial' čo v Česku len 4,7 \% (Musil - Müller 2008: 330).

8 Pre podrobnejšie údaje a štatistiky pozri (Chorvát 2019b).
} 
cii. Rozdiel v rozvinutosti tejto siete môžeme dobre ilustrovat' na plávaní ako jednej z univerzálnych športových aktivít. Verejných plaveckých bazénov je v ČR 957 resp. 9,1 na stotisíc obyvatel'ov. Za Slovensko nemáme k dispozícii presné údaje, na základe dostupných informácií možno ich počet odhadnút' na približne 220 (avšak vrátane nie vždy verejnosti prístupných hotelových a wellness bazénov), čo je len približne 4,1 bazénu na stotisíc obyvatel'ov (Chorvát 2019b). Spolu so skutočnost'ou, že verejné bazény vo viacerých slovenských mestách úplne absentujú, to jasne ilustruje zhoršenú dostupnost' podmienok pre trávenie vol'ného času športovaním na Slovensku. Nepriamo to dokumentujú aj dáta o vyššej úrovni športovej organizovanosti v ČR (ibid.), lebo jedným z dôvodov vyššieho počtu registrovaných členov je aj hustejšia a dostupnejšia infraštruktúra športovísk.

\section{Výskumné otázky a hypotézy}

Ciel’om tejto štúdie je na základe empirických analýz dát z výskumov trávenia vol’ného času dospelej populácie uskutočnených v druhej dekáde 21 . storočia vyhodnotit', či je možné pozorovat' v českej a slovenskej spoločnosti podobné sociodemograficko-ekonomické determinanty v hlavných oblastiach trávenia vol'ného času.

V prvom kroku preto identifikujeme hlavné sféry trávenia vol'ného času, ktoré reprezentujú základné životné štýly. Podrobnejšiemu rozboru štruktúry vol’nočasových aktivít sa tu z dôvodu obmedzeného rozsahu štúdie podrobnejšie nevenujeme. Na základe predchádzajúcich výsledkov na spojenom dátovom súbore za obe krajiny, ako aj oddelene pre Česko a Slovensko (pozri Chorvát Šafr 2019), vychádzame z predpokladu, že v obidvoch spoločnostiach existuje viacmenej zhodná základná štruktúra trávenia vol’ného času, t. j. vzájomná väzba medzi určitými aktivitami, ktoré l’udia vykonávajú či naopak, ktorým sa nevenujú alebo sa im venujú s nižšou intenzitou. Presnejšie povedané, že je možné na českú a slovenskú spoločnost' so štatisticky prijatel'nou mierou zhody aplikovat' totožnú základnú štruktúru aktivít vol'ného času. Tento predpoklad v druhom kroku overujeme pomocou Prokrustovej analýzy, ktorá nám umožní komplexné porovnávanie dvoch viacrozmerných priestorov tvorených väzbami vol’nočasových aktivít identifikovaných oddelene v ČR i SR.

Druhá - hlavná čast' analýz sa venuje výskumnej otázke, čo určuje trávenie vol'ného času $v$ jednotlivých sférach, a predovšetkým či tieto determinanty pôsobia $\mathrm{s}$ rovnakou intenzitou $\mathrm{v}$ oboch spoločnostiach. Overujeme vyššie zmieňované predpoklady o vplyve jednotlivých sociodemograficko-geografických faktorov. Medzi takto potenciálne odlišne pôsobiacimi faktormi sme na základe vyššie uvedeného porovnania štrukturálnych podmienok našich spoločností identifikovali tri najvýznamnejšie - vel'kost' miesta bydliska, vek a vzdelanie. Overujeme tak nasledujúce hypotézy o odlišnom pôsobení týchto

Sociológia 53, 2021, č. 2 
troch hlavných determinantov na spôsob trávenia vol’ného času v Česku a na Slovensku:

Odlišná rezidenčná štruktúra a s ňou späté inštitucionálne zázemie vedie $\mathrm{k}$ vyššiemu vplyvu vel'kosti miesta bydliska na Slovensku než v Česku (H1). Východiskom tejto hypotézy je existencia vyššej disperzie regionálnych centier v ČR, ako aj ich relatívne vyšší počet. Ide o mestá, ktoré poskytujú zázemie pre aktívnejšie formy trávenia vol'ného času, t. j. tie, ktoré sú závislé na dostupnej verejnej infraštruktúre tzv. mestskej kultúry (divadlá, koncertné sály, kiná, knižnice, náročnejšie športové zariadenia atd'.). Slovensko sa tiež vyznačuje pomerne vysokou mierou rurality, čo znamená nielen nižšiu dostupnost' zázemia v regionálnych centrách, ale tiež určitú zakorenenost' tradičnejších hodnotových orientácií zameraných na lokalitu a rodinu.

Rozdiely (aj ked' nie príliš výrazné) v demografickej skladbe obyvatel'stva (najmä odlišná veková štruktúra a jej previazanost' so štruktúrou vzdelania v najstarších kohortách) vedú k vyššiemu vplyvu veku na Slovensku než $v \check{C}$ esku, a to aj pri kontrole vplyvu vzdelania (H2).

Na základe poznatkov modernizačnej teórie (faktor oneskorenej modernizácie na Slovensku) očakávame vyšši vplyv vzdelania na Slovensku než v Česku, a to aj pri kontrole vplyvu veku (H3).

Pripomeňme, že hodnota označujúca vek v sebe nenesie len informáciu o biologickom veku a teda $\mathrm{z}$ hl'adiska životného cyklu aj o príslušnosti $\mathrm{k}$ nejakej mladšej či staršej vekovej kohorte, ale aj informáciu o podmienkach, v ktorých bol jedinec socializovaný v určitom spoločensko-historickom kontexte. $\mathrm{V}$ tejto súvislosti je dôležité, že hodnoty a základné kultúrne vzorce (vkus) sú socializované už v ranom detstve. Východiskom je tu predpoklad, že čistý vplyv biologického veku (životnej fázy) na spôsob trávenia vol'ného času je v oboch spoločnostiach rovnaký. V najmladších kohortách rozdiely medzi Českom a Slovenskom nepredpokladáme, lebo tie sú v rovnakej miere vystavené kultúrne homogénnym vplyvom šíriacim sa v rámci globalizácie. Predpokladáme však, že staršie vekové kohorty prežili obdobie primárnej socializácie $\mathrm{v}$ trochu odlišných podmienkach. Ako sme už uviedli, vzdelanostná štruktúra v Česku a na Slovensku sa vo vekovo starších kohortách líši, v priemere vyššie vzdelanie (t. j. najmä nižšie zastúpenie základného vzdelania) dosahujú staršie kohorty v Českej republike. Môžeme predpokladat', že staršie generácie zažili svoje detstvo (hovoríme približne o 40. až 60. rokoch 20. storočia) v trochu odlišnom kultúrno-vzdelanostnom milieu, ked’že hodnoty a kultúrne orientácie boli cez generáciu ich rodičov stále $\mathrm{v}$ nemalej miere späté aj s étosom prozápadnej modernity prvej republiky, ktorý bol zrejme silnejšie prítomný v českej spoločnosti. Predovšetkým sa však rodičovská generácia súčasných najstarších českých kohort vyznačovala vyššou vzdelanostnou úrovňou ako u ich rovesníkov na Slovensku a v čase ich dospievania mali české krajiny výraznejší 
náskok v miere urbanizácie než tomu bolo neskôr v kohortách dospievajúcich od 70. rokov 20. storočia, kedy už bola dôslednejšie realizovaná koncepcia strediskovej sústavy osídlenia, ktorej ciel'om bolo zabezpečit' dostupnost' občianskej vybavenosti a zníženie rozdielov medzi mestom a vidiekom.

Vplyv interakcie vzdelania $s$ vekom nám však môže čiastočne a aspoň nepriamo odpovedat' na otázku, či sa v trávení vol'ného času prejavuje na národnej úrovni odlišný kohortno-socializačný efekt. Preto formulujeme ešte štvrtú hypotézu o tom, že najvyšši vplyv vzdelania na trávenie volného času sa bude na Slovensku prejavovat' v najstaršej vekovej kategórii nad 65 rokov (H4).

Tieto hypotézy overujeme postupne $\mathrm{v}$ troch oblastiach trávenia vol'ného času, ktoré reprezentujú všeobecnejšie typy životného štýlu (pozri d'alej).

\section{Použité dáta}

Využívame dáta $\mathrm{z}$ dvoch výskumov, ktoré boli čiastočne koordinované v oboch republikách, v ČR je to výskum Kultura v regionech České republiky (2011) a v SR Vol'ný čas a sociálna štruktúra na Slovensku (2016), v ktorých sme sa priamo zamerali na problematiku vol'ného času, kultúrnej participácie a vkusu. Koordinácia výskumov nám umožnila - síce $\mathrm{s}$ istým časovým posunom replikovat' na Slovensku čast' otázok, ktoré sa ukázali byt' pri skúmaní vol'ného času, kultúrnej participácie a vkusu v Česku podstatné (pozri Chorvát - Šafr eds. 2019) a vytvorit’ tak unikátnu spoločnú harmonizovanú dátovú bázu Volný čas a kultura v ČR a SR $(2011 / 2016)^{9}$. Popis výskumov, v obidvoch prípadoch založených na kvótnom výbere, je spolu s podrobnejšími deskriptívnymi štatistikami uvedený v (ibid.: 232-237). Analytický súbor použitý v tejto štúdií bol zúžený na jedincov od 21 rokov, celkom 3441 prípadov (ČR 2496 a SR 945). Týmto krokom eliminujeme subpopuláciu s dosial' neukončenou vzdelávacou dráhou - študentov stredných škôl, u ktorých predpokladáme existenciu špecifických vzorcov trávenia vol'ného času zodpovedajúcich skôr životnému štýlu typickému pre mládež.

\section{Vol'nočasové aktivity na Slovensku a v Česku}

Skôr než pristúpime k analýze determinantov vol’ného času, aspoň v krátkosti porovnáme intenzitu, s akou sa Česi a Slováci venujú jednotlivým aktivitám. Ďalej preskúmame, či existuje nejaký vzájomný vzt’ah medzi týmito aktivitami,

\footnotetext{
${ }^{9}$ Pochopitel’ne sme si vedomí, že medzi realizáciou týchto výskumov uplynulo takmer pät' rokov, a tak aj výsledky týkajúce sa popisu situácie v slovenskej a v českej spoločnosti tým môžu byt' čiastočne skreslené (aj ked’ reálne sa to týka zrejme iba používania PC a internetu), domnievame sa však, že tento časový odstup nie je taký vel'ký, aby nám neumožňoval uskutočnit' komparáciu hlavných kontúr štruktúry mimopracovného života a ich determinantov v našich spoločnostiach.
} 
či teda môžeme hovorit' o nejakej inherentnej a v rámci sledovaných spoločností analogickej štruktúre trávenia vol'ného času.

Základné obrysy intenzity zhodne meraných 21 vol'nočasových aktivít (pozri poznámku 12) v SR a Č́R uvádza graf č. 1 (obsahuje tiež výsledky testov rozdielov v priemerných hodnotách medzi krajinami). Na základe podobného rozloženia ich hodnôt a priemerných intenzít vykonávaných činností môžeme konštatovat', že $\mathrm{v}$ druhom desat'ročí 21 . storočia sa trávenie vol'ného času $\mathrm{v}$ našich spoločnostiach $\mathrm{v}$ princípe podobá, avšak s nasledujúcimi výnimkami ${ }^{10}$. V populácii starších ako 21 rokov Česi častejšie čítajú noviny a knihy, sledujú filmy na $\mathrm{DVD} / \mathrm{videu} / \mathrm{PC}$, o niečo viac sledujú televíziu a chodia na prechádzky či výlety do prírody. Naopak, dospelí obyvatelia Slovenska viacej navštevujú ako diváci športové podujatia a tiež sa častejšie venujú manuálnym prácam ako je majstrovanie či šitie, s trochu väčšou intenzitou sa venujú i starostlivosti o seba (wellness, solárium, kozmetický salón, sauna, a pod.) ${ }^{11}$. Otázkou však zostáva, či takúto globálnu podobnost' nájdeme aj pri vnútornej štruktúre jednotlivých aktivít vol’ného času a faktoroch, ktoré jeho trávenie ovplyvňujú.

\footnotetext{
${ }^{10}$ Aj ked’ štatisticky významné rozdiely na základe párových t-testov nachádzame u väčšiny aktivít, z vecného hladiska je dôležitá ich vel'kost' (tzv. effect size). Zdôraznime, že ani najväčší rozdiel v priemeroch nedosahuje vel'kosti hodnoty jednej celej kategórie $\mathrm{v}$ odpovediach $\left(0,88 \mathrm{v}\right.$ prípade čítania novín, $\left.\mathrm{Eta}^{2}=0,053\right)$. Ako vecne významné komentujeme rozdiely, kde krajina vysvetl'uje viac ako $1 \%$ variancie v hodnotách príslušnej aktivity $\left(\operatorname{Eta}^{2} \times 100\right)$.

${ }^{11}$ Zrejme neprekvapí, že najvýraznejší rozdiel by sme našli v prípade účasti na bohoslužbách, ktorá je na Slovensku výrazne vyššia než v Česku, pravidelne (t. j. minimálne raz za mesiac) ich tu navštevuje 42 \% obyvatelov, kým v ČR len $11 \%$ (podrobnejšie pozri Chorvát - Šafr 2019). Túto aktivitu tu ale úmyselne neberieme do úvahy. Vedie nás k tomu domnienka, že účast' na bohoslužbách pôsobí skôr ako obmedzujúci faktor vol'ného času (je to v istom zmysle pre veriaceho ,povinnost" či záväzok a v tomto zmysle sa svojou podstatou skôr zhoduje s činnost’ami, ktoré obyčajne vyčleňujeme ako viazaný čas, medzi ktoré patria aj činnosti spojené s osobnou starostlivost’ou - v prípade náboženstva ale nejde o starostlivost' o fyzické potreby, ale o uspokojenie potrieb duchovných). Toto chápanie je v súlade s klasickým vymedzením vol’ného času J. Dumazediéra, ktorý z vol'ného času vylučuje školské, profesionálne, občianske či náboženské činnosti, t. j. tie, ktoré sú určované materiálnou potrebou či morálnym alebo spoločenským imperatívom (Dumazedier 1966). Zároveň si uvedomujeme, že ide o významnú zložku komunitného spoločenského života, ktorá má potenciál ovplyvňovat' štruktúru vol'nočasových aktivít nielen počas nediel' či náboženských sviatkov. Druhým a pre účely tohto textu rozhodujúcim argumentom je však fakt, že našim ciel’om je testovanie hypotéz o špecificky národných vplyvoch na rovnaké vol'nočasové sféry, t. j. primárne neporovnávame štruktúru vol’nočasových aktivít v Čechách a na Slovensku, ale ide nám tu o určenie determinantov pôsobiacich na ( $\mathrm{v}$ zásade) podobnú štruktúru. Dodajme, že návšteva bohoslužieb je typická pre oblast' trávenia vol'ného času orientovanú na domáckost' a rodinu, a to na Slovensku aj v ČR, a ak by sme do tejto dimenzie zahrnuli aj návštevy bohoslužieb, potom by jej celková intenzita bola na Slovensku vyššia.
} 
Graf č. 1: Aktivity vol'ného času, percentá, priemery, párové t-testy a Eta², SR 2016, ČR 2011
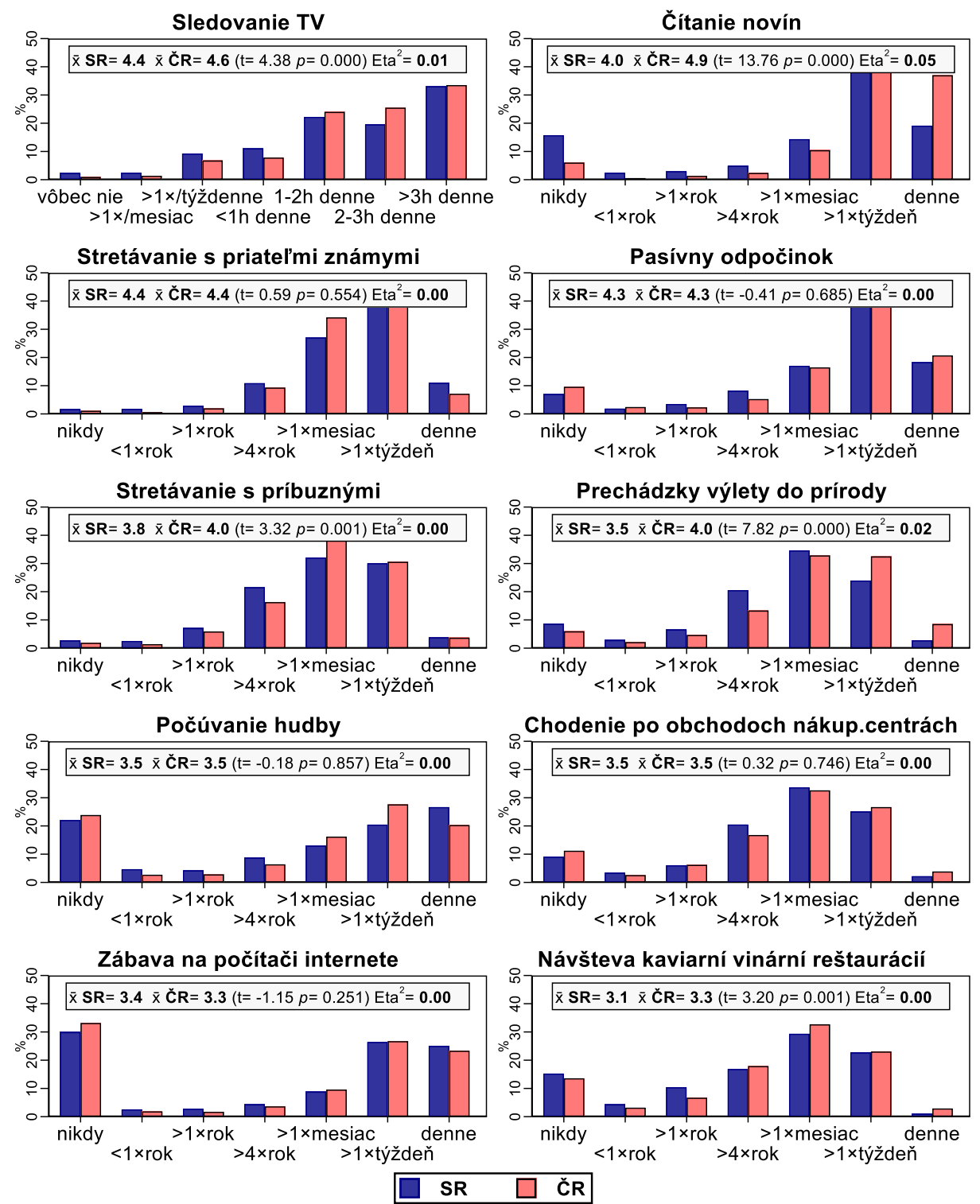

Graf pokračuje na d'alšej strane.

Sociológia 53, 2021, č. 2 

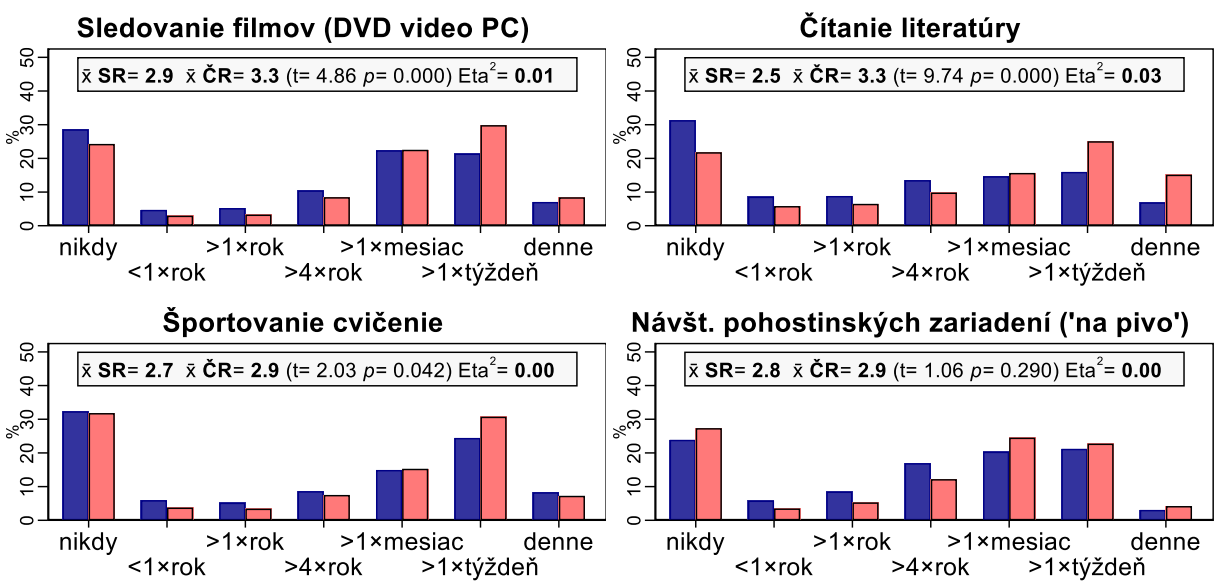

Návšt. pohostinských zariadení ('na pivo')
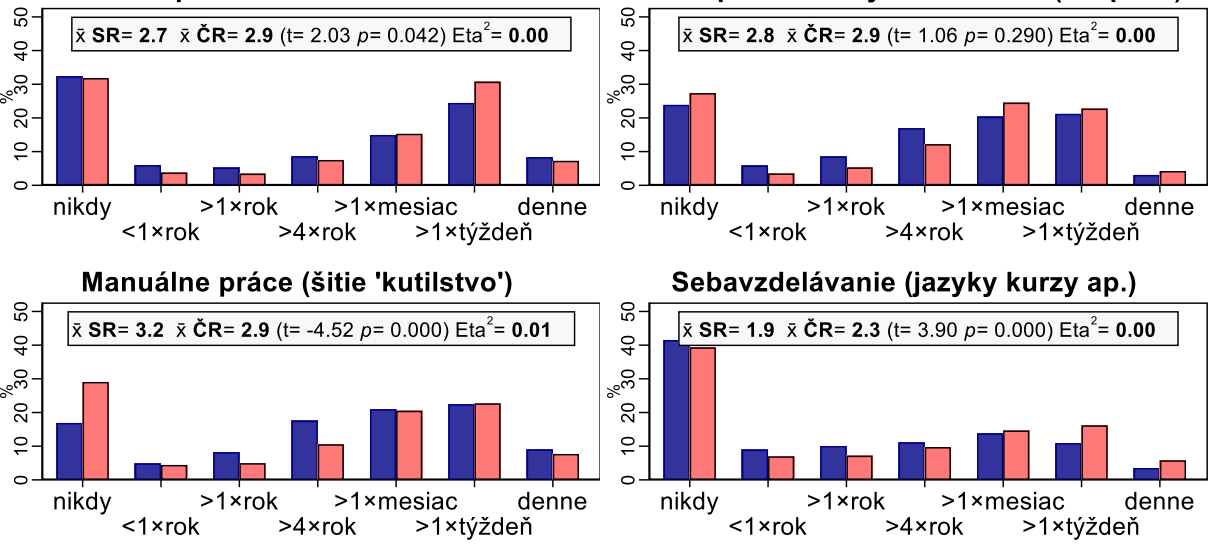

Sebavzdelávanie (jazyky kurzy ap.)
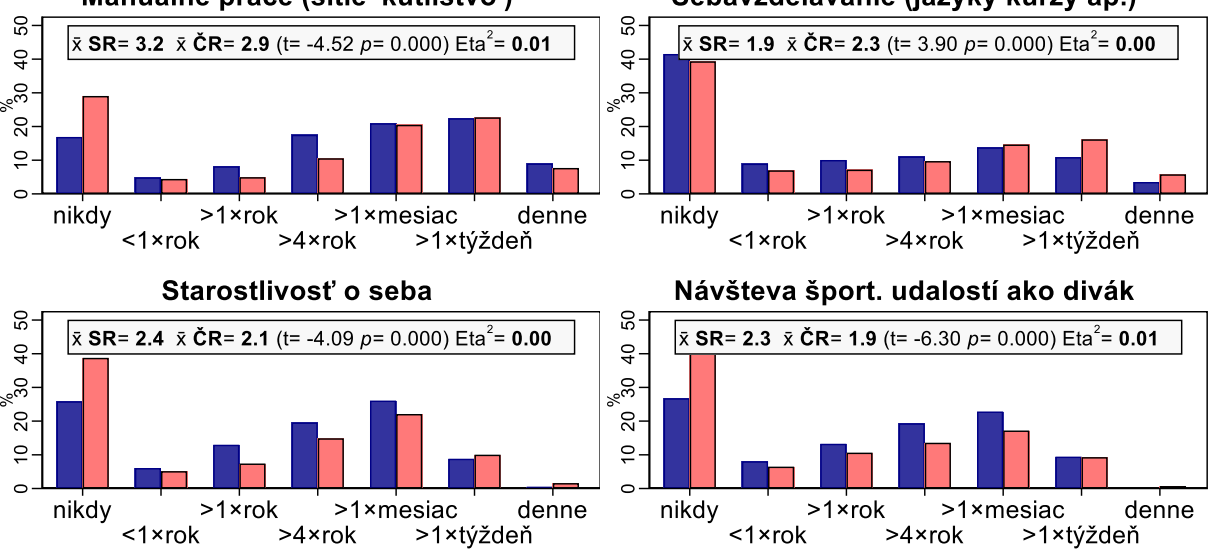

Návšteva šport. udalostí ako divák
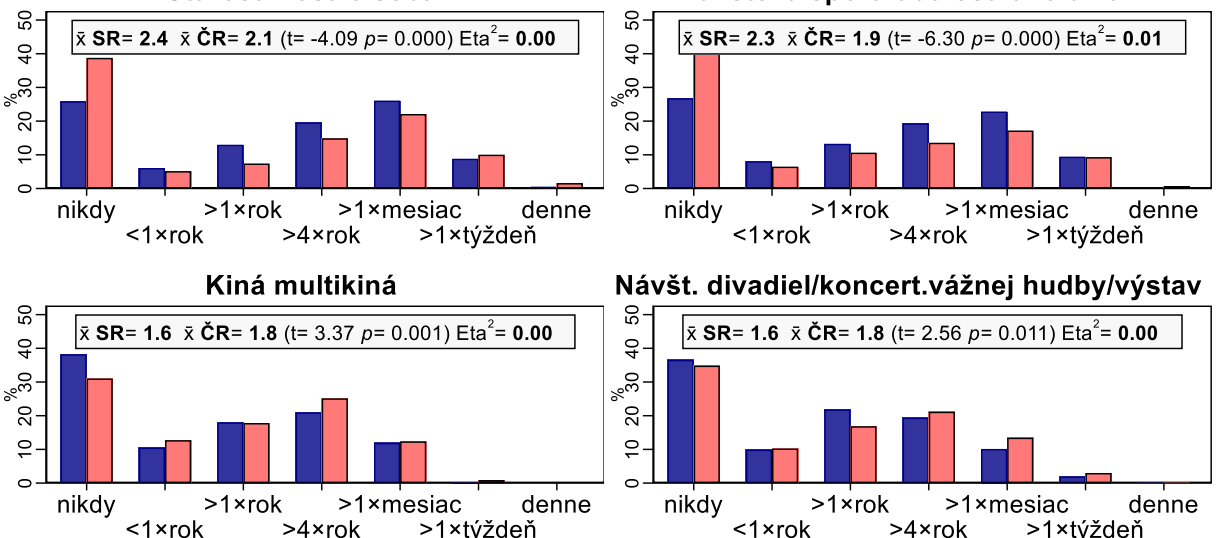

Návšt. divadiel/koncert.vážnej hudby/výstav

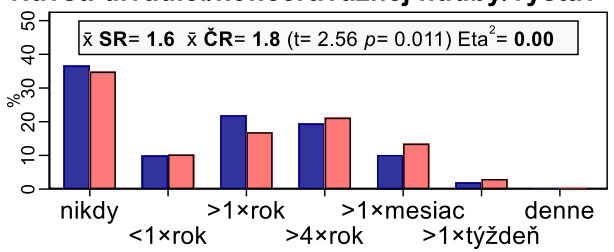

Návšteva diskoték tanečných akcií

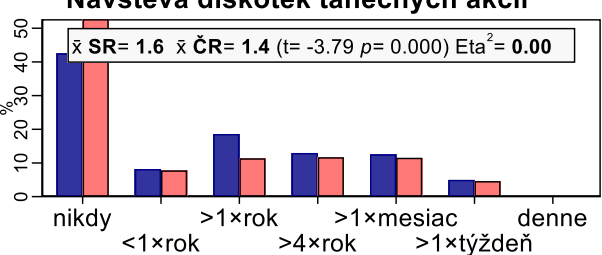

Zdroj: Volný čas a kultura ČR 2011, SR 2016 


\section{Štruktúra trávenia vol'ného času}

$\mathrm{Na}$ overenie národných odlišností týkajúcich sa vplyvu rôznych faktorov na spôsoby trávenia vol'ného času treba najskôr zadefinovat' jednotlivé všeobecnejšie sféry späté s odlišným životným štýlom, ktoré sú dané inherentnou logikou sociálneho pol'a a kultúrneho vkusu. Ked’že ciel’om tejto štúdie nie je podrobnejšia analýza prípadných odlišností v tejto štruktúre, na rozkrytie ich vnútornej previazanosti a identifikáciu hlavných sfér trávenia vol’ného času využijeme exploračnú faktorovú analýzu na spojenom súbore dát za Českú republiku a za Slovensko (konkrétne metódu principal factoring a šikmú rotáciu faktorov). Na vysvetlenie poznamenáme, že analýzu sme najskôr realizovali samostatne za obe republiky (pozri d’alej), čo ukázalo na niektoré čiastkové rozdiely. Na tomto mieste však prezentujeme výsledky na spojenom dátovom súbore, pretože našim hlavným ciel’om je ukázat', v ktorej oblasti trávenia vol'ného času sa medzi obomi spoločnost’ami líšia vplyvy vybraných sociodemografických charakteristík - preto bolo nutné pracovat's rovnakými dimenziami za obidve republiky. Identifikovat' je možné tri hlavné sféry vol’ného času manifestujúce všeobecnejšie životné štýly (pozri tabul'ku č. 2): aktívny životný štýl s väzbou na vysokú kultúru; zábavu mimo domov a konzumáciu nových médií, a trávenie vol'ného času doma späté s rodinným životom.

Prvý typ aktivít zahŕňa jednak orientáciu na kultúrne náročnejšiu formu trávenia vol'ného času a na osobný rozvoj (návšteva divadiel, koncertov a galérií, čítanie beletrie a sebavzdelávanie), ako aj starostlivost' o seba (wellnes, kaderníctvo, kozmetika) a chodenie „po obchodoch, nákupných centrách“, t. j. nie za účelom zabezpečovania základných komodít, ale hlavne kvôli prezeraniu módneho tovaru a držaniu kroku s aktuálnymi trendmi. Patrí sem aj športovanie, chodenie na prechádzky a turistika, ale čiastočne tiež sledovanie filmov a zábava na počítači/internete. Tieto formy trávenia vol'ného času nepochybne v sebe často zahŕňajú snahu demonštrovat' a potvrdzovat' sociálny status a preto reprezentujú (a tiež vyžadujú) vtelený kultúrny kapitál.

Druhá sféra činností vol’ného času tvorí orientáciu na zábavu a to v dvoch okruhoch. Po prvé mimo domova, kde ide predovšetkým o aktivity typické pre mužov, či už návštevu pohostinských zariadení (tzv. chodenie na pivo), účast' na športových podujatiach, alebo aj rodovo neutrálnejšie návštevy reštaurácií, kaviarní, diskoték, koncertov populárnej hudby, alebo navštevovanie sa s priatel'mi a známymi. U tých, ktorí sa venujú týmto činnostiam, je príznačný tiež aktívny záujem o šport. Po druhé k nim patrí konzumácia médií, predovšetkým tých nových. Okrem počúvania hudby tu nájdeme i čas strávený zábavou na počítači/internete a sledovanie filmov doma (na DVD, počítači, internete...).

Sociológia 53, 2021, č. 2 
Tretí typ životného štýlu, tvorený najmenej vykryštalizovaným faktorom, je charakteristický jednak orientáciou na rodinu - stretávaním sa s príbuznými, ako aj trávením vol'ného času doma resp. v miestnej lokalite, či už pasívne pred televíznou obrazovkou a odpočinkom - ničnerobením, prípadne čítaním novín (aj ked' čítanie novín je najmenej vyprofilovanou aktivitou resp. premennou $\mathrm{s}$ minimálnou zát’ažou naprieč všetkými faktormi), ale aj aktívne v podobe prechádzok, výletov a rozvíjania rôznych koníčkov, záluub, ručných prác a prác na záhrade či opráv domu apod. Dodajme, že výskum v ČR dve naposledy zmieňované formy trávenia vol'ného času (práce na záhrade, údržba domu či auta) detailnejšie nesledoval a tak presnejšie porovnanie tu nemáme $\mathrm{k}$ dispozícii $^{12}$. Platí, že táto oblast' vol’ného času sa vyznačuje najnižšou vysvetlenou varianciou, no na jej plauzibilnost' ukazuje záporná korelácia s druhými dimenziami.

Nechceme tým povedat', že empiricky identifikované dimenzie, ktoré spoločne vysvetlujú $43 \%$ variancie v hodnotách pôvodných premenných, pokrývajú celú širokú komplexitu rozličných foriem trávenia vol’ného času. Fakticky odrážajú iba bazálnu typológiu životného štýlu danú predovšetkým kultúrnym vkusom a fázou životného cyklu ${ }^{13}$.

\footnotetext{
12 Táto položka nebola meraná v oboch výskumoch rovnakým spôsobom. Skonštruovali sme preto binárny indikátor, ktorý vznikol v dátach zo slovenského výskumu z odpovedí na dve uzavreté otázky (vždy sme brali do úvahy odpoved' s vyššou frekvenciou): „A ako často sa venujete...?““ „práci na záhrade, práci na domácom hospodárstve, starostlivosti o zvieratá“ a „opravám a údržbe domu, chaty alebo auta“" pri frekvencii aspoň raz za týždeň. V českom výskume sme využili významom zodpovedajúce odpovede na tri prepojené otvorené otázky „Č́m se nejraději zabýváte ve volném čase?“ Naše dáta ukazujú v SR $57 \%$ a v ČR $26 \%$ respondentov, ktorí sa venujú uvedeným domácim činnostiam intenzívne. Navyše vy̌šiu obl'úbenost' týchto činností na Slovensku potvrdzuje aj výsledok z najnovšieho výskumu kultúrneho kapitálu a trávenia vol'ného času v ČR z prelomu roka 2019 - 2020, kde identicky formulované a rovnako prekódované otázky identifikujú v ČR 34 \% l’udí aktívnych v prácach okolo domu a záhrady. Zaradenie tohto indikátora považujeme za dôležité - už sme uvádzali, že väčšina výskumov sa sústred’uje predovšetkým na kultúrne aktivity realizované hlavne v mestskom prostredi a opomína bežné činnosti vol'ného času typickejšie pre vidiek. I z dôvodov takto dichotomicky konštruovanej premennej je vstupná matica pre faktorovú analýzu založená na polychorických koreláciách.

13 Pochopitel'ne že, náš mimopracovný život je ovel'a pestrejší. Ako sme ukázali na inom mieste (Chorvát - Šafr 2019: 120123), tieto bazálne životné štýly možno d'alej podrobnejšie rozčlenit' do minimálne piatich špecifických sfér trávenia vol'ného času: vysoká kultúra; zábava mimo domova - tzv. „,mužský svet“; ,,̌̌enský svet“ viazaný na rodinu a známych; pasívnu formu vol’ného času doma / konzumáciu médií typickú pre mladých; pasívnu formu vol'ného času, tzv. „domáckost““. Ked’že ciel'om tejto štúdie je rigorózny test hypotéz o národných špecifikách vol’nočasových determinantov, obmedzujeme sa tu pre úspornost' výkladu iba na uvedenú základnú typológiu troch všeobecných rysov životného štýlu, ktoré zodpovedajú dimenziám identifikovaným na dátach za dlhšie obdobie po roku 1989 v Českej republike (Šafr 2012).
} 
Tabul'ka č. 2: Štruktúra vol’nočasových aktivít: faktorová analýza (principal factoring), faktorové zát'aže, jedinečnosti, šikmá rotácia Oblimin, SR 2016, ČR 2011

\begin{tabular}{lrrrr}
\hline & Dim. 1 & Dim. 2 & Dim. 3 & Jedinečnost' \\
\hline Návšteva divadiel, koncertov vážnej hudby, & $\mathbf{0 , 7 3 5}$ & $-0,030$ & 0,068 & 0,479 \\
výstav & $\mathbf{0 , 7 2 1}$ & 0,007 & $-0,085$ & 0,455 \\
Sebavzdelávanie (jazyky, kurzy ap.) & $\mathbf{0 , 6 5 1}$ & $\mathbf{- 0 , 2 9 4}$ & 0,130 & 0,590 \\
Č́́tanie literatúry & $\mathbf{0 , 5 9 3}$ & 0,178 & $-0,006$ & 0,552 \\
Starostlivost' o seba & $\mathbf{0 , 5 8 0}$ & 0,230 & $-0,083$ & 0,504 \\
Športovanie, cvičenie & $\mathbf{0 , 4 9 5}$ & $\mathbf{0 , 3 4 9}$ & $-0,205$ & 0,430 \\
Kiná, multikiná & $\mathbf{0 , 4 7 0}$ & 0,013 & $\mathbf{0 , 3 5 9}$ & 0,690 \\
Prechádzky, výlety do prírody & $\mathbf{0 , 3 0 7}$ & 0,129 & 0,210 & 0,850 \\
Chodenie po obchodoch, nákupných centrách & $\mathbf{- 0 , 2 7 0}$ & 0,069 & $\mathbf{0 , 2 6 5}$ & 0,855 \\
Sledovanie TV & $\mathbf{- 0 , 2 5 3}$ & $\mathbf{0 , 7 8 6}$ & 0,020 & 0,441 \\
Návšteva pohostinských zariadení ('na pivo') & 0,087 & $\mathbf{0 , 7 2 9}$ & 0,022 & 0,431 \\
Návšteva kaviarní, vinární, reštaurácí́ & 0,219 & $\mathbf{0 , 5 9 5}$ & $-0,206$ & 0,411 \\
Návšteva diskoték, tanečných akcií & 0,018 & $\mathbf{0 , 5 7 3}$ & $\mathbf{0 , 3 1 8}$ & 0,649 \\
Stretávanie s priatel'mi, známymi & 0,142 & $\mathbf{0 , 5 2 2}$ & 0,007 & 0,666 \\
Návšteva športových udalostí ako divák & $\mathbf{0 , 2 5 9}$ & $\mathbf{0 , 4 7 4}$ & $-0,176$ & 0,555 \\
Sledovanie filmov (DVD, video, PC) & $\mathbf{0 , 2 9 3}$ & $\mathbf{0 , 4 4 3}$ & $-0,207$ & 0,541 \\
Zábava na počítači, internete & $\mathbf{0 , 3 3 3}$ & $\mathbf{0 , 3 8 1}$ & $-0,127$ & 0,620 \\
Počúvanie hudby & 0,152 & 0,205 & $\mathbf{0 , 4 2 4}$ & 0,792 \\
Stretávanie s príbuznými & 0,175 & $-0,087$ & $\mathbf{0 , 4 1 5}$ & 0,800 \\
Manuálne práce (šitie, ,kutilstvo“) & $-0,065$ & $-0,102$ & $\mathbf{0 , 3 3 9}$ & 0,845 \\
Práca na záhrade; oprava údržba domu, chaty, & $-0,209$ & 0,241 & $\mathbf{0 , 2 6 4}$ & 0,874 \\
auta & 0,163 & 0,110 & 0,191 & 0,932 \\
Pasívny odpočinok & $18,4 \%$ & $17,8 \%$ & $6,5 \%$ & \\
Noviny (čítanie) & & & & \\
\hline Vysvetlená variancia & $\quad$ ccelkovo 42,8 \%) & & \\
\hline & & & & \\
& & &
\end{tabular}

Poznámka: vstupná matica polychorických korelácií, na extrakciu faktorov bolo použité Kaiserovo kritérium, rotácia Oblimin, zvýraznené koeficienty s $>0,25$; korelácie faktorov: f1 a f2 r = 0,30; f2 a f3 r = -0,23; f1 a f3 $=-0,12$.

Zdroj: Volný čas a kultura ČR 2011, SR 2016

Aby sme overili platnost' východiskovej tézy, že základná štruktúra vol’ného času je v Česku a na Slovensku v zásade rovnaká, urobili sme v d’alšom kroku faktorovú analýzu taktiež pre obidve krajiny samostatne a následne sme takto vzniknuté dva viacrozmerné priestory vol'nočasových aktivít porovnali pomocou Prokrustovej analýzy. Tá poskytuje odpoved' na otázku, do akej miery sa prekrývajú dve alebo viac konfigurácií bodov. Tie môžu byt' 
orientované odlišne a tiež ich mierka môže byt' iná. Prokrustova analýza rieši tento problém tak, že považuje jednu z konfigurácií ako cielovú, v našom prípade ČR, a tú optimálne pomocou vhodných transformácií (tu používame šikmú rotáciu) prispôsobuje tak, aby bola čo najviac podobná druhej zdrojovej konfigurácii (SR). Výsledky pre prvé dve dimenzie uvádza graf č. 2, v ktorom sú zobrazené podobnosti $\mathrm{v}$ skúmaných štruktúrach trávenia vol'ného času (podrobnejšie vrátane tretej dimenzie pozri prílohu tabul'ku č. A1). Výsledná mapa vol'nočasových aktivít $\mathrm{v}$ podstate zobrazuje priestor životných štýlov v dvojdimenzionálnej rovine, horizontálna os ukazuje na polaritu medzi nízkou/masovou (sledovanie TV, ničnerobenie) a vysokou kultúrou (sebavzdelávanie, chodenie do divadla, na koncerty a výstavy), respektíve pri určitom zjednodušení medzi pasívnym a aktívnym životným štýlom. Vertikála, aj ked' zd’aleka nie tak výrazne, odkazuje k dualite ženského a mužského sveta (napr. čítanie kníh vs. chodenie na pivo). Dôkaz o skutočne minimálnych rozdieloch medzi obomi krajinami poskytuje pohl'ad na graf, v ktorom je na prvý pohlad' zrejmé, že jednotlivé vol'nočasové aktivity v ČR transformované na pozíciu podl'a SR sú vel'mi blízko seba ${ }^{14}$. Oprávnenost' nášho predpokladu o zhodnosti štruktúry trávenia vol’ného času v ČR a SR je navyše podporená aj štatistickými kritériami, ked' dosahuje vel'mi nízke hodnoty $0,0896^{15}$ aj štatistika Procrustes, aj miera celkového vzájomného tzv. fit modelu pre SR na model pre ČR (RMSE 0,0883) ${ }^{16}$.

\footnotetext{
14 Najväčšia vzdialenost', to znamená odlišnost' pozície v štruktúre vol'ného času v ČR a SR je pri chodení do kaviarní, vinární, reštaurácií apod. (pozri štatistiku Q v tabul'ke č. A1), ale aj tá je v princípe totožná, lebo tieto aktivity sa nachádzajú $\mathrm{v}$ susedstve $\mathrm{v}$ rovnakom kvadrante.

15 Štatistika Procrustes je definovaná ako podiel RSS (residual sum of squares, sčítané za všetky premenné v ČR) / SS (total sum of squares, sčítané za všetky premenné v ČR), meria vel'kost' reziduálov vzhl'adom k variancii v ciel'ových premenných (tu ako faktorová štruktúra aktivít v SR). V zásade ide o ekvivalent miery 1 - R2 tak ako ju poznáme z regresnej analýzy. Čím je štatistika Procrustes menšia, tým je korelačná štruktúra trávenia vol'ného času z faktorovej analýzy v ČR zhodnejšia so štruktúrou v SR.

16 RMSE (root mean squared error) je miera priemernej vel'kosti reziduálov, konkrétne ide o druhú odmocninu strednej kvadratickej reziduálnej chyby (RSS). Meria celkovú mieru toho, ako model „sedi““ (tzv. fit).
} 


\section{Graf č. 2: Prokrustova analýza. Podobnost' štruktúry vol’nočasových aktivít v SR a v ČR}

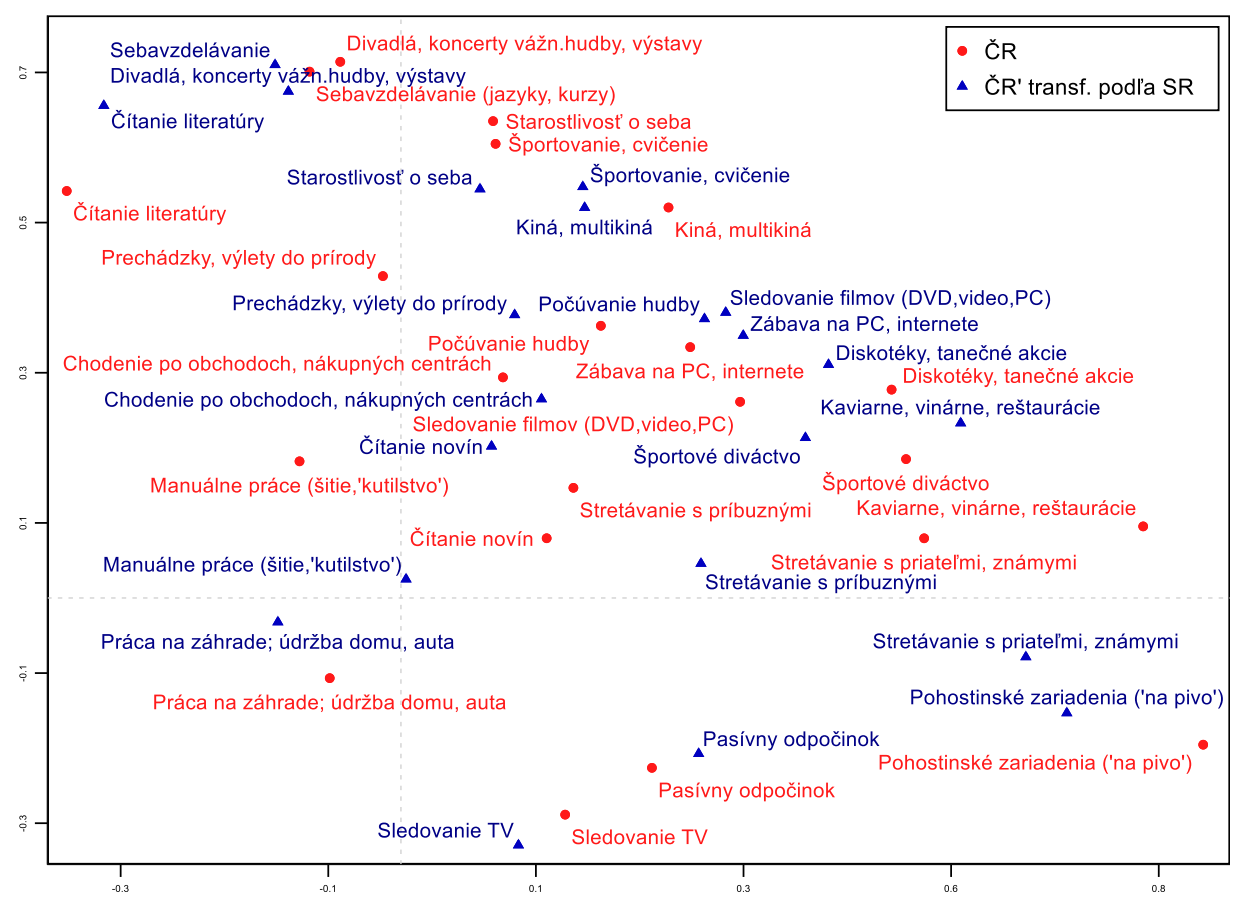

Poznámka: zobrazený prvý a druhý faktor a ich transformácie (zlícovanie ČR na SR) v ortogonálnej rotácii. Zdroj: Volný čas a kultura ČR 2011, SR 2016

\section{Sú determinanty hlavných sfér trávenia vol’ného času národne špecifické?}

Na naplnenie ciel’a štúdie sme d’alej odhadli regresné modely na zlúčených dátach za obidve krajiny, $\mathrm{v}$ ktorých vysvetl'ujeme rozptyl $\mathrm{v}$ hodnotách jednotlivých troch latentných premenných reprezentujúcich hlavné sféry trávenia vol’ného času (faktorových skóre). Modely testujú hypotézy o odlišnom vplyve klúčových vysvetl'ujúcich premenných, t. j. veku, vzdelania a vel'kosti bydliska. Zároveň obsahujú aj kontrolné kovariáty, pri ktorých doterajšie výskumy preukázali vplyv na trávenie vol'ného času: pohlavie, rodinný stav, skutočnost', či opýtaný má deti (vo veku do 18 rokov) a príjem domácnosti (pre porovnatel'nost' transformovaný na kvintily). Rigorózne zhodnotenie rozdielov medzi ČR a SR naznačených v našich hypotézach je pri každej sfére vol'ného času založené na časti modelu zahŕňajúcom interakciu s indikátorovou premennou odlišujúcou naše republiky. 
Tabul'ka č. 3: Determinanty troch sfér trávenia vol'ného času, odhady neštandardizovaných koeficientov z OLS modelu, SR 2016, ČR 2011

\begin{tabular}{|c|c|c|c|c|c|c|}
\hline Hlavné efekty: & \multicolumn{2}{|c|}{$\begin{array}{l}\text { (1) } \\
\text { Aktívny životný štýl/ } \\
\text { vysoká kultúra }\end{array}$} & \multicolumn{2}{|c|}{$\begin{array}{l}\text { Zábava mimo domova/ } \\
\text { nové médiá }\end{array}$} & \multicolumn{2}{|c|}{$\begin{array}{c}(3) \\
\text { Domácnost'/ rodina }\end{array}$} \\
\hline Žena & $0,284^{* * *}$ & $(0,000)$ & $-0,418^{* * *}$ & $(0,000)$ & $0,156^{* * *}$ & $(0,000)$ \\
\hline Vek & $-0,013^{* * *}$ & $(0,000)$ & $-0,029^{* * *}$ & $(0,000)$ & $0,023^{* * *}$ & $(0,000)$ \\
\hline Rodinný stav: Slobodný & 0,048 & $(0,301)$ & $0,107^{*}$ & $(0,013)$ & $-0,171^{* * *}$ & $(0,000)$ \\
\hline Má nezaopat. deti <18rok. & 0,047 & $(0,214)$ & $-0,055$ & $(0,122)$ & 0,042 & $(0,201)$ \\
\hline Príjem domácn., kvintily & $0,107^{* * *}$ & $(0,000)$ & $0,050^{* * *}$ & $(0,000)$ & 0,000 & $(0,974)$ \\
\hline Vzdelanie: SS̆ & $0,757^{* * *}$ & $(0,000)$ & 0,305 & $(0,090)$ & 0,098 & $(0,563)$ \\
\hline VŠ & $1,048^{* * *}$ & $(0,000)$ & $-0,236$ & $(0,322)$ & 0,166 & $(0,459)$ \\
\hline Vel'kost' bydliska & $0,068^{* * *}$ & $(0,000)$ & $0,071^{* * *}$ & $(0,000)$ & $-0,023$ & $(0,086)$ \\
\hline C̆R & 0,265 & $(0,110)$ & $0,457^{* *}$ & $(0,003)$ & 0,023 & $(0,876)$ \\
\hline \multicolumn{7}{|l|}{ Interakcie pre krajiny: } \\
\hline$\check{\mathrm{C}} \mathrm{R} \times \mathrm{SS}$ & $-0,353$ & $(0,124)$ & $-0,538^{*}$ & $(0,012)$ & $-0,038$ & $(0,849)$ \\
\hline ČR $\times$ V $\breve{S}$ & $-0,436$ & $(0,151)$ & $-0,263$ & $(0,351)$ & $-0,101$ & $(0,702)$ \\
\hline ČR $\times$ Vek & 0,002 & $(0,463)$ & $-0,003$ & $(0,220)$ & $-0,000$ & $(0,851)$ \\
\hline $\mathrm{SS} \times$ Vek & $-0,008^{*}$ & $(0,046)$ & $-0,006$ & $(0,125)$ & $-0,004$ & $(0,211)$ \\
\hline $\mathrm{VŠ} \times \mathrm{Vek}$ & $-0,004$ & $(0,433)$ & 0,010 & $(0,058)$ & $-0,006$ & $(0,187)$ \\
\hline$\breve{\mathrm{C} R} \times \mathrm{SS} \times$ Vek & 0,008 & $(0,088)$ & $0,011^{* *}$ & $(0,010)$ & 0,001 & $(0,892)$ \\
\hline$\check{\mathrm{C}} \mathrm{R} \times \mathrm{V} \check{\mathrm{S}} \times \mathrm{Vek}$ & 0,008 & $(0,200)$ & 0,000 & $(0,940)$ & 0,000 & $(0,956)$ \\
\hline ČR $\times$ Vel'kost' bydliska & $-0,040^{*}$ & $(0,032)$ & $-0,062^{* * *}$ & $(0,000)$ & $-0,003$ & $(0,868)$ \\
\hline Konštanta & $-0,552^{* * *}$ & $(0,001)$ & $1,114^{* * *}$ & $(0,000)$ & $-0,966^{* * *}$ & $(0,000)$ \\
\hline Adj. $R^{2}$ & 0,314 & & 0,393 & & 0,251 & \\
\hline $\mathrm{N}$ & 2901 & & 2901 & & 2901 & \\
\hline
\end{tabular}

Poznámka: $p$-hodnoty v zátvorkách; ${ }^{*} p<0,05 ;{ }^{* *} p<0,01 ;{ }^{* * *} p<0,001$

Referenčné kategórie: muž; ženatý/vydatá alebo rozvedený/rozvedená; nemá deti vo veku do 18 rokov; základné vzdelanie alebo vyučenie bez maturity; SR

Zdroj: Volný čas a kultura ČR 2011, SR 2016

Najprv však aspoň stručne vo všeobecnosti k vplyvom na trávenie vol’ného času v oboch republikách (pozri výsledky v prvom paneli v tabul'ke č. 3). Aktívny životný štýl/participácia na vysokej kultúre je typický pre ženy, vyššie príjmové kategórie a viac sa mu venujú tiež mladší l’udia. Podl'a očakávania vel'ký vplyv má vzdelanie, najviac chodia do divadla, na koncerty vážnej hudby a číajú knihy l’udia s vysokoškolským vzdelaním. Intenzita trávenia vol'ného času týmto spôsobom rastie rovnako s vel'kost'ou bydliska, čo je primárne dané dostupnost'ou siete kultúrnych inštitúcií v mestskom prostredí. Zábavu mimo domov spolu s konzumáciou nových médii celkom očakávane vyhl'adávajú hlavne mladí l'udia a muži, skôr slobodní, s vyšším príjmom domácnosti a takisto tí, ktorí žijú v mestskom prostredí. Poznamenávame, že 
pri kontrole sociodemografikých charakteristík za naše populácie je iba táto sféra vol'ného času o niečo typickejšia pre Českú republiku. Tretia sféra podomácky trávený vol’ný čas a orientácia na rodinu je spoločensky najmenej diferencovaná. Zhruba povedané, je akýmsi protipólom tej predchádzajúcej (hoci v obidvoch sférach je relatívne významne zastúpené „,ničnerobenie“). Typická je skôr pre starších l’udí, ženy, a vydaté resp. ženatých či rozvedených.

Nezodpovedanou otázkou ale zostáva, či je aj intenzita vplyvu týchto vysvetl'ujúcich faktorov v Česku i na Slovensku rovnaká. V teoretickej časti sme argumentovali, že historicko-spoločenský vývoj medzi našimi spoločnost’ami bol predsa len $\mathrm{v}$ niektorých ohl'adoch trochu odlišný a preto sme formulovali štyri hypotézy o odlišnom pôsobení vel'kosti miesta bydliska, veku, vzdelania ako aj vzdelania v kombinácii s vekom (nepriamo meraný kohortný efekt). Ich overeniu sa venuje druhá čast' modelov s interakčnými efektmi pre tieto vybrané faktory s krajinou (pozri druhý panel v tabul'ke č. 3), ktorá bola doplnená aj dodatočnými posthoc t-testami pre párové porovnanie štatistickej významnosti rozdielov všetkých kategórií v interakciách (ktoré z dôvodu úspory miesta neuvádzame). Výsledky kvôli väčšej prehl'adnosti prezentujeme s pomocou predikcie hodnôt závislej veličiny.

$\mathrm{Na}$ základe predikovaných hodnôt pre SR a ČR (uvádza ich graf č. 3) a výsledkov posthoc t-testov možno konštatovat', že pokial' ide o prvú hypotézu, väšší vplyv vel'kosti miesta bydliska sa prejavuje na Slovensku. Záleží pritom ale na konkrétnej oblasti trávenia vol'ného času. V prípade Aktívneho životného štýlu/vysokej kultúry, kde v ČR nájdeme rozdiely medzi vel'kost’ami sídel menšie ako na Slovensku, sú v tomto smere najmenej aktívni obyvatelia malých - vidieckych sídel na Slovensku, zatial' čo vo vel'kých mestách je ich aktivita rovnaká ako u mestských obyvatelov Česka. Pri druhej sfére - Zábave mimo domova/konzumácie nových médií je interakčný efekt tiež viditelný, priebeh je ale nepatrne odlišný: kým v Českej republike sa rozdiely v intenzite v závislosti na vel'kosti sídla prakticky neprejavujú, tak na Slovensku je tento spôsob trávenia vol’ného času najmenej častý vo vidieckych sídlach (do 5 tis. obyvatel'ov). Na druhej strane v najväšších sídlach nad 100 tisíc obyvatel'ov (v slovenských reáliách sú to iba Bratislava a Košice) dokonca predbiehajú obyvatel'ov Česka žijúcich v podobne vel'kých mestách. Pri tretej oblasti Domáckost'/rodina nie sú rozdiely podl'a vel'kosti miesta bydliska vo väzbe na republiku významné. Znamená to teda, že prvá hypotéza platí v prvej a druhej sfére vol'ného času a v tretej oblasti neplatí.

Druhá hypotéza predpokladá silnejší vplyv veku na Slovensku. Jej platnost' však môžeme prijat' len v prípade Aktívneho životného štýlu/vysokej kultúry, vo zvyšných dvoch oblastiach ju zamietame. V najmladšej vekovej skupine sa obyvatelia Slovenska a Česka v aktívnom životnom štýle nelíšia, na Slovensku 
však afinita $\mathrm{k}$ tomuto spôsobu trávenia vol’ného času klesá $\mathrm{s}$ rastúcim vekom strmšie než v Česku.

Tretia hypotéza predpokladá, že dosiahnutá úroveň vzdelania bude mat' väčší vplyv na podoby trávenia vol'ného času na Slovensku než v Česku. Na základe výsledkov ju nemôžeme jednoznačne zamietnut' $\mathrm{v}$ dvoch sledovaných oblastiach, jej platnost' však napriek tomu nie je taká jednoznačná ako pri predchádzajúcich dvoch hypotézach. Republikovo odlišný vplyv vzdelania je viditel'ný pri Aktívnom životnom štýle/vysokej kultúre, môžeme tu však hovorit' skôr o aditívnom vplyve než o interakčnom efekte, pretože pri všetkých vzdelanostných kategóriách v Česku platí, že sú vo vol’nom čase aktívnejšie resp. že vo väčšej miere konzumujú vysokú kultúru než rovnaké vzdelanostné kategórie na Slovensku. V prípade trávenia vol'ného času zábavou mimo domova/konzumáciou nových médií je $\mathrm{v}$ súlade $\mathrm{s}$ našou hypotézou zrejmá iba jedna odchýlka, a síce že vysokoškolsky vzdelaní obyvatelia Slovenska sú oproti českým v tejto sfére aktívnejšši ${ }^{17}$.

Ako sa efekty zmenia, ked' zohl'adníme previazanost' vzdelania s vekom, reprezentujúcu do značnej miery historicko-generačné rozdiely? Odpoved’ na túto otázku dáva test štvrtej hypotézy, ktorá predpokladá, že tento kombinovaný (trojitý) interakčný efekt bude silnejší na Slovensku. Aj tomto prípade záleží na tom, o akú sféru trávenia vol’ného času ide (pozri graf č. 4). Republikovo generačne podmienený efekt vzdelania je zrejmý $\mathrm{v}$ prípade aktívneho životného štýlu/vysokej kultúry, hoci interakčný efekt je presvedčivo prítomný (štatisticky významný) iba $\mathrm{v}$ prípade stredoškolského a vysokoškolského vzdelania. Platí, že v najmladších skupinách (približne do necelých 40 rokov veku) rozdiely medzi krajinami nie sú pozorovatel'né, ale s rastúcim vekom sa v oboch vzdelanostných kategóriách zvyšujú (u vysokoškolákov je tento rozdiel štatisticky významný až od veku 55 rokov). Pri nižšej úrovni vzdelania (základné a vyučení) je však výsledok sporný. S výnimkou najmladšej kohorty (okolo 25 rokov), kde rozdiel nie je štatisticky preukázatel’ný, Česi majú väčšiu afinitu $\mathrm{k}$,aktívnemu životnému štýlu/vysokej kultúre“ než rovnako vzdelaní Slováci, v oboch prípadoch ale táto afinita s vekom klesá zhruba rovnako, preto pri nižšom vzdelaní môžeme pozorovat' skôr aditívny efekt (hoci nulový rozdiel medzi obomi republikami pri najmladšej vekovej kategórii by vo svojom dôsledku aj tu čiastočne dokumentoval prítomnost' vel'mi slabého interakčného efektu). Môžeme tak konštatovat', že platnost' hypotézy o odlišnom vplyve vzdelania $\mathrm{v}$ závislosti na veku sa $\mathrm{v}$ tejto prvej sfére presvedčivo preukázala iba pri vysokoškolskom a stredoškolskom stupni vzdelania.

\footnotetext{
17 Tento rozdiel, platný iba v prípade vysokoškolákov, potvrdil aj dodatočný post-hoc test párových rozdielov medzi skupinami.
} 
Graf č. 3: Predikované hodnoty troch sfér trávenia vol'ného času, interakcie vel'kosti obce, veku a vzdelania s krajinou $z$ regresného modelu, SR 2016, ČR 2011

\section{Aktívny životný štýl/vysoká kultúra}

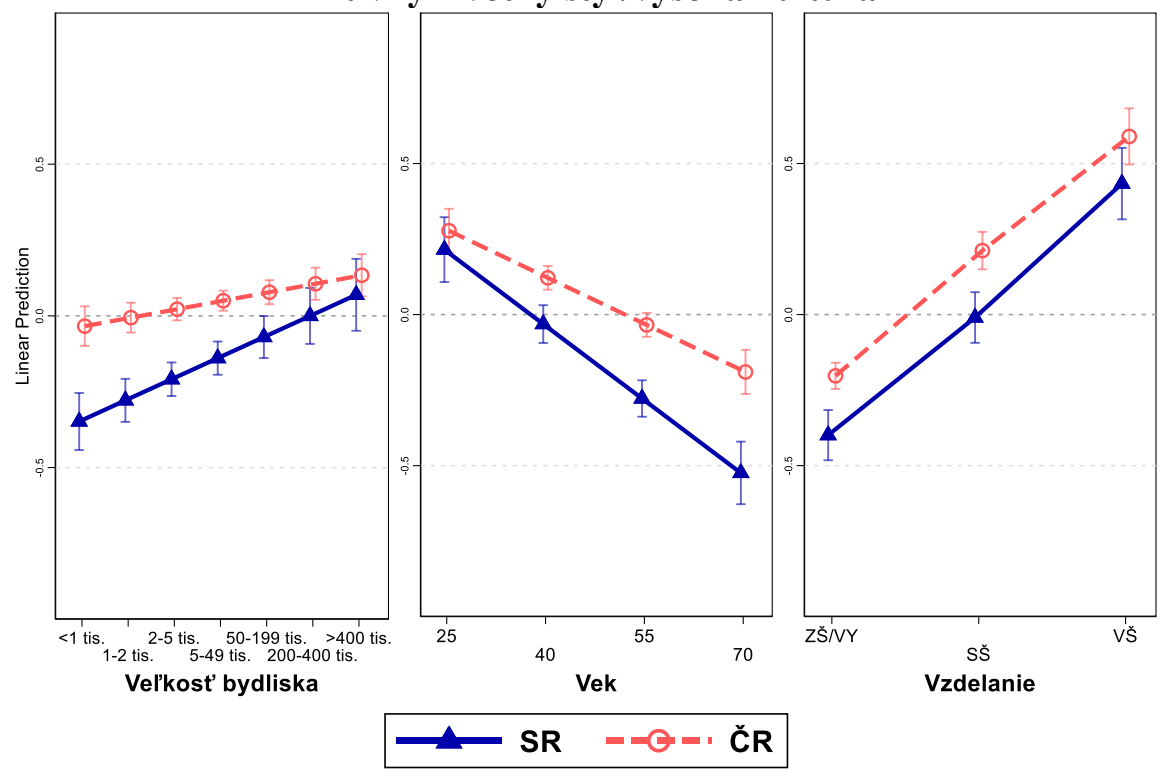

Zábava mimo domova/nové médiá

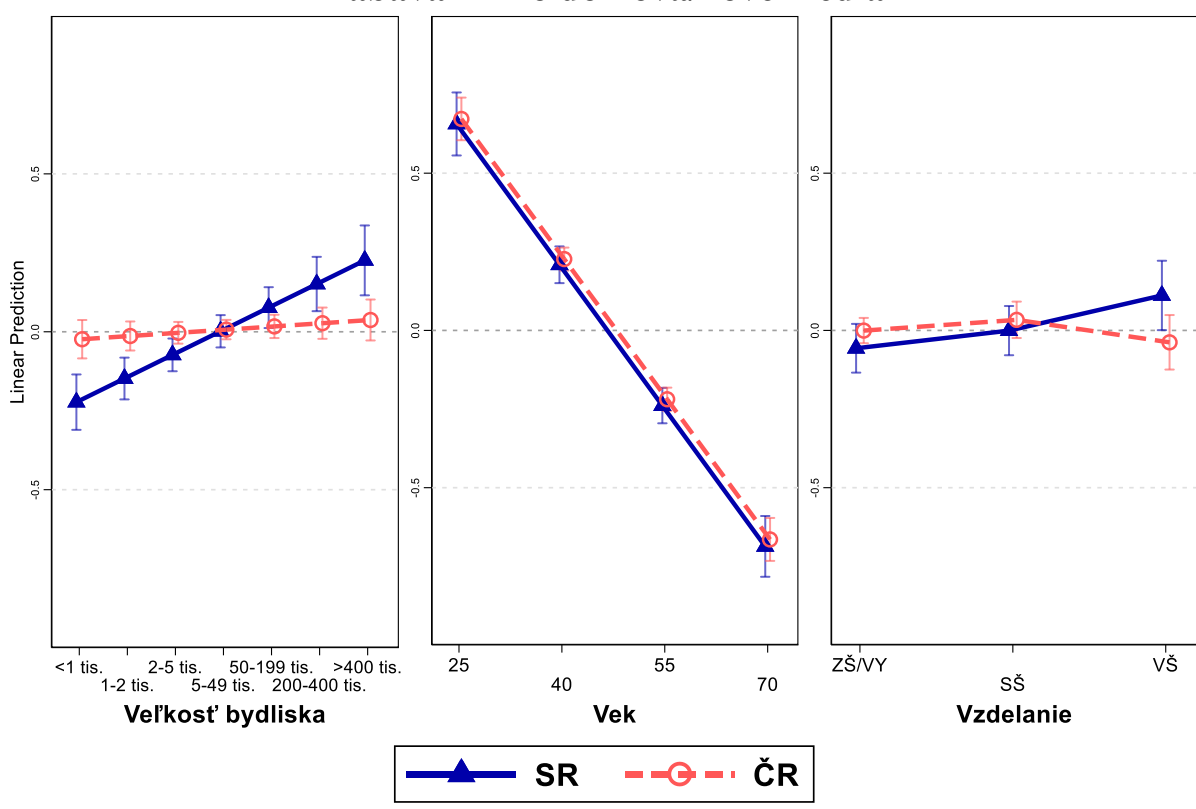

Sociológia 53, 2021, č. 2 


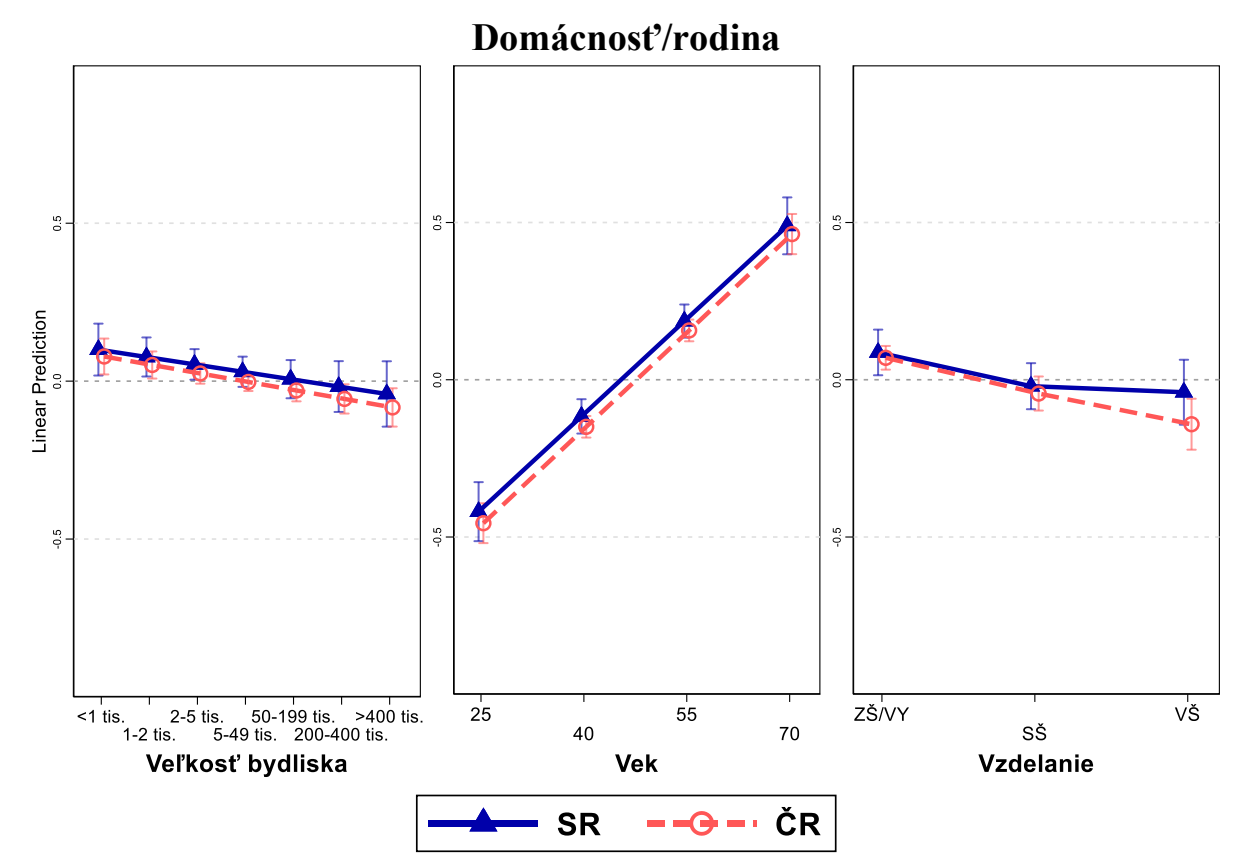

Zdroj: Volný čas a kultura ČR 2011, SR 2016

Pokial' ide o druhú sféru - trávenie vol’ného času zábavou mimo domova alebo s novými médiami, štvrtú hypotézu z väčšej časti zamietame, lebo pri základnom a vysokoškolskom vzdelaní nie je preukázatel'ný žiadny (interakčný ani aditívny) efekt (u vysokoškolákov je síce štatisticky významný aditívny efekt vo veku 40-55 rokov, ale ten nemôžeme považovat' za monotónny trend). Len pri stredoškolákoch sa očakávaný previazaný vplyv s vekom čiastočne prejavuje, a to u l'udí nad 55 rokov, kde je táto forma trávenia vol'ného času na Slovensku menej intenzívna a s rastúcim vekom sa tento rozdiel d’alej zvyšuje.

V prípade tretej sféry hypotézu 4 úplne zamietame, lebo - ako je zrejmé z grafu - ani pri jednej z kategórií vzdelania nenachádzame medzi Čechmi a Slovákmi pozdíž hodnôt veku výraznejšie rozdiely. Inými slovami, nepozorujeme tu ani interakčný, ani aditívny efekt.

Ak to zhrnieme, môžeme konštatovat', že štvrtá hypotéza platí, ale opät' len v prvej sfére aktívneho životného štýlu/vysokej kultúry a čiastočne aj v prípade sféry zábavy mimo domova resp. konzumácie nových médií. 
Graf č. 4: Predikované hodnoty troch sfér trávenia vol'ného času, trojité interakcie veku, vzdelania a krajiny $z$ regresného modelu, SR 2016, ČR 2011
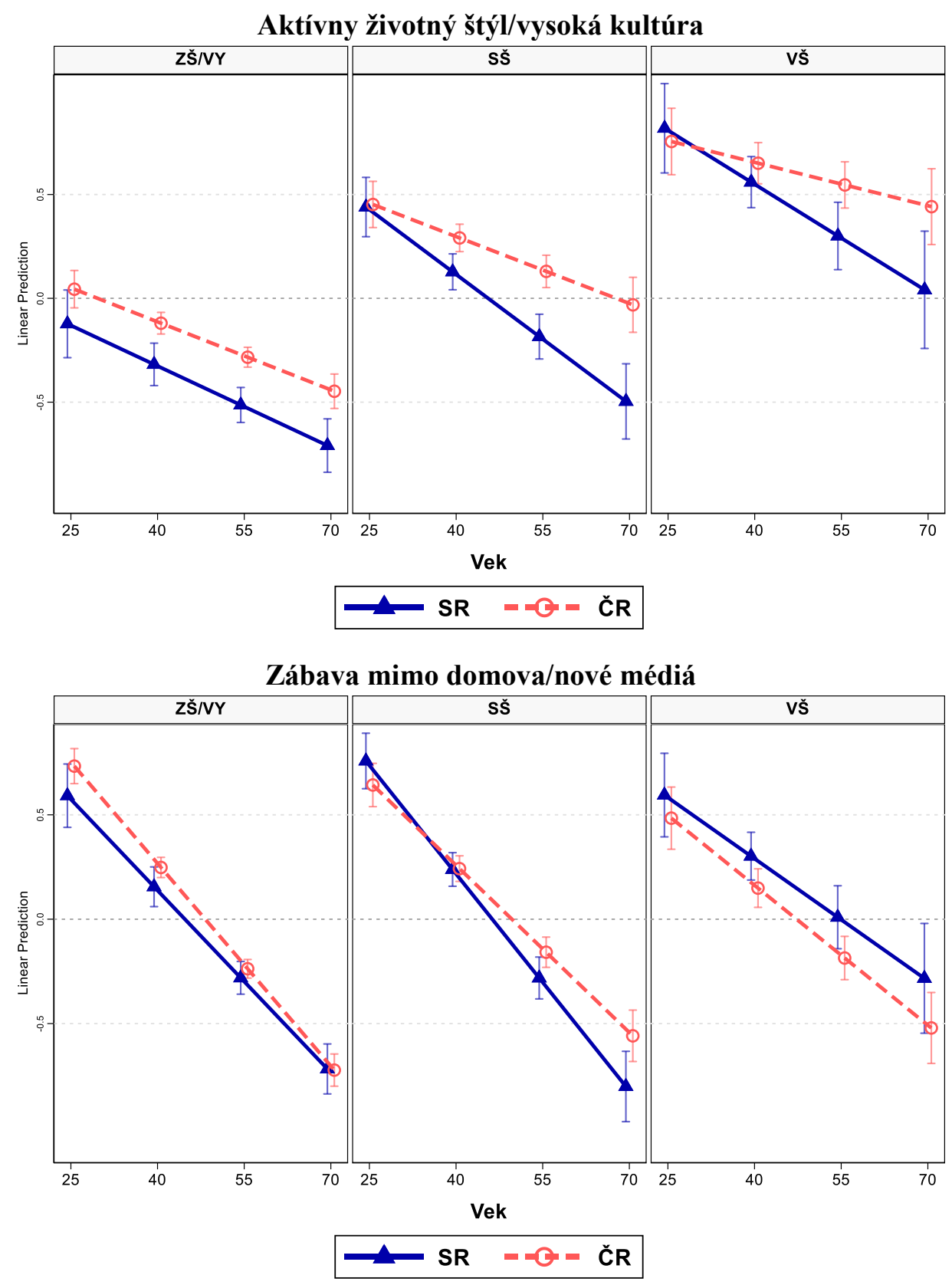

Sociológia 53, 2021, č. 2 


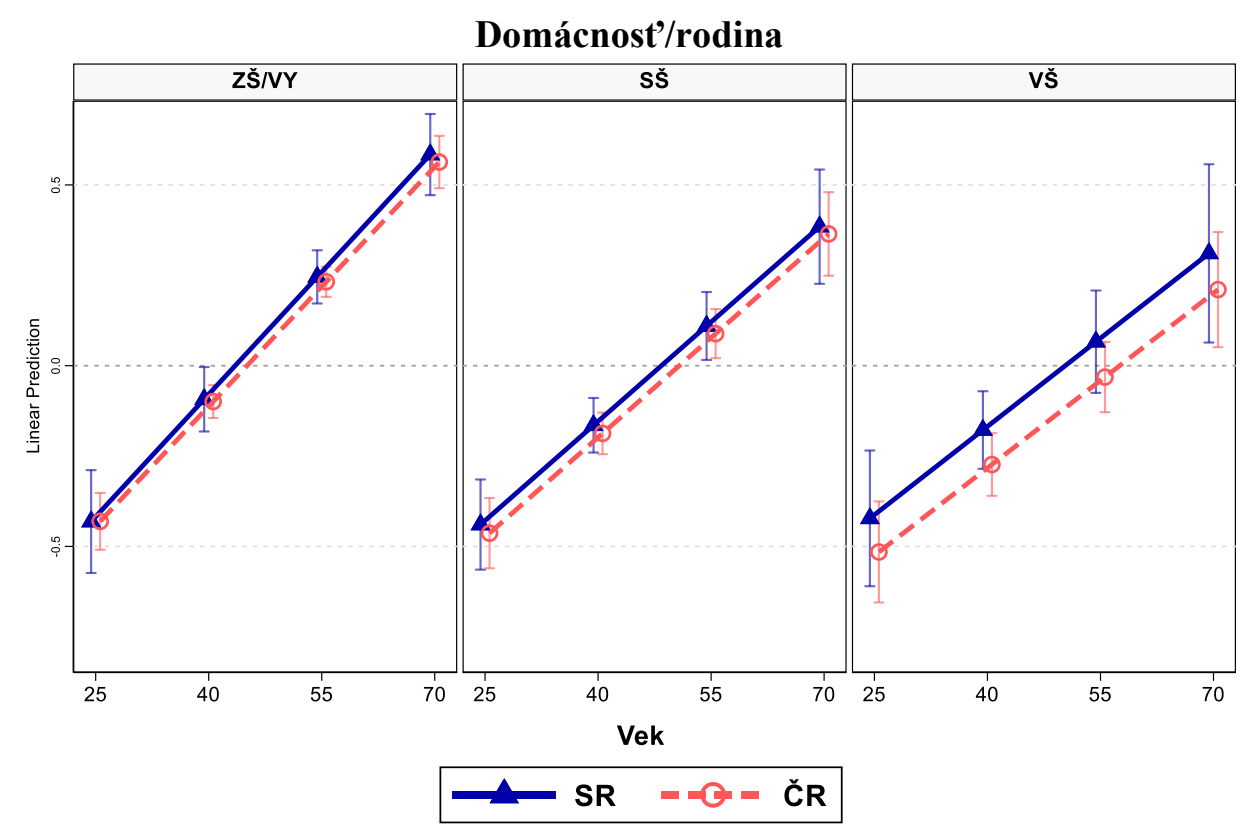

Zdroj: Volný čas a kultura ČR 2011, SR 2016

\section{Záver}

Našou snahou bolo zhodnotit' determinanty trávenia vol'ného času obyvatel'ov dvoch susediacich a historicky i kultúrne blízkych štátov - Česka a Slovenska. Z hladiska sledovaných ukazovatel'ov trávenia vol'ného času sa v tom, čomu sa vo vol’nom čase v súčasnosti venujeme, naše spoločnosti výraznejšie nelíšia. Potvrdili sme aj základnú podobnost' vnútornej štruktúry vol’nočasových aktivít v obidvoch spoločnostiach, pričom sme identifikovali tri štýlotvorné sféry: 1 . štýl, v ktorom vystupujú do popredia záujmy spájané s vysokou kultúrou a celkovo aktívnym spôsobom trávenia vol’ného času; 2. životný štýl spájaný so zábavou mimo domova, ktorá $\mathrm{v}$ dnešnej dobe ide často ruka v ruke $\mathrm{s}$ obluubou konzumácie nových médií (internet); 3. spôsob života, ktorý je typický dôrazom na trávenie vol'ného času doma a viazaný na činnosti s členmi rodiny či domácnosti, charakteristická je preň určitá lokálnost' a „domáckost'“. Toto rozčlenenie základných sfér vol’ného času vyjadrujúce odlišné životné štýly nám umožnilo sledovat' rozdiely $\mathrm{v}$ efektoch štrukturálnych podmienok, pri ktorých naše hypotézy očakávali odlišnú silu vplyvu v Česku a na Slovensku. Špecificky sme sa pritom v hypotézach zamerali na republikovú odlišnost' vplyvu vel'kosti bydliska, veku, vzdelania, respektíve vzdelania v kombinácii 
s vekom. Výsledky regresných analýz ukázali, že sa tieto faktory ovplyvňujúce trávenie vol'ného času čiastočne na Slovensku a v Česku líšia.

Národné odlišnosti $\mathrm{v}$ sledovaných vplyvoch sa najviac prejavujú pri aktívnom životnom štýle/vysokej kultúre; najmenší, respektíve žiadny rozdiel možno nájst' u vol'ného času tráveného doma resp. v rodinnom kruhu. Pre tento vol’nočasový životný štýl teda platí, že tí, čo ho v Česku i na Slovensku preferujú, sa od seba výraznejšie nelíšia ani z hl'adiska vel'kosti bydliska, ani vekovo či v úrovni dosiahnutého vzdelania a ani historicko-generačne (t. j. v kombinácii veku a vzdelania).

Zábave mimo domova resp. sledovaniu nových médií sa Česi venujú približne v rovnakej intenzite bez ohl'adu na to, či bývajú vo väčšom meste alebo na dedine, kým na Slovensku najmä bývanie na vidieku (v sídlach menších ako 5 tisíc obyvatel'ov) značne limituje obyvatel'ov v možnostiach íst' sa vonku zabavit'. Podobne pri činnostiach, ktoré si vyžadujú aktívnejšie zapojenie, výraznejšiu osobnostnú investíciu a kultúrnu orientáciu (čítanie kníh, športovanie, návštevy divadiel, koncertov, výstav ale aj chodenie po nákupných centrách a starostlivost' o seba), ktoré sme zhrnuli pod označenie aktívny životný štýl/vysoká kultúra, nachádzame republikové rozdiely nielen z hl'adiska vel'kosti sídla, ale tiež veku a čiastočne aj vzdelania a dokonca i pri vzájomnej previazanosti vzdelania s vekom. Súhrnne môžeme povedat', že pri tomto životnom štýle, ktorý kultúrny kapitál jednak vytvára a zároveň určitý predchádzajúci objem vteleného kultúrneho kapitálu vyžaduje (habitus), nachádzame najväčšie rozdiely medzi republikami (v neprospech obyvatel'ov Slovenska) v malých sídlach, vo vyšších vekových kategóriách a pri l'ud'och so stredoškolským a vysokoškolským vzdelaním, pri ktorých sa navyše rozdiely voči rovnako vzdelaným Čechom s rastúcim vekom prehlbujú.

Možné vysvetlenie týchto rozdielov vidíme $\mathrm{v}$ popísaných štrukturálnych odlišnostiach Slovenska a Česka, predovšetkým v diferenciách v sídelnej štruktúre (faktor urbánnejšej a modernejšej českej spoločnosti) a s ňou nepriamo súvisiacej infraštruktúrnej vybavenosti, ktorá sa prejavuje v zníženej dostupnosti a menšej hustote siete zariadení na trávenie vol'ného času v menších sídlach a vo vidieckych oblastiach Slovenska. V SR po roku 1990 naviac dochádzalo $\mathrm{k}$ d’alšiemu prehlbovaniu medziregionálnych rozdielov, čo viedlo k vytváraniu rozsiahlejších periférnych či marginalizovaných území, ktoré sa v Českej republike v takej výraznej podobe a na tak rozl'ahlom území nevyskytujú, pričom práve tie vytvárajú d’alšie bariéry $\mathrm{v}$ možnostiach kultúrno a športovo náročnejších foriem trávenia vol'ného času.

Rolu tu zohrávajú aj d'alšie historicko-kultúrne okolnosti skoršej modernizácie a urbanizácie českej spoločnosti, z ktorých, aj vo svetle poznatkov z nášho výskumu, by sme ešte vyzdvihli vyššiu mieru vzdelanostnej úrovne prejavujúcu sa u starších vekových kohort, a z toho vyplývajúcu vyššiu mieru

Sociológia 53, 2021, č. 2 
medzigeneračne odovzdávaného kultúrneho kapitálu u tých Čechov, ktorí $\mathrm{v}$ našom výskume patria $\mathrm{k}$ najstarším vekovým kohortám - v priemere boli vychovávaní rodičmi s vyšším dosiahnutým vzdelaním, kým v prípade strednej a mladšej generácie už medzi obomi republikami výraznejšie vzdelanostné rozdiely (máme na mysli vzdelanie a socializačné pôsobenie generácií ich rodičov) pravdepodobne nenájdeme.

Naše závery potvrdzujú zistenia z viacerých zahraničných výskumov, ktoré ako hlavné determinujúce faktory trávenia vol'ného času uvádzajú vek a vzdelanie. Čiastočne potvrdzujú aj tie závery, ktoré za d’alší dôležitý faktor považujú vel'kost' bydliska - tento vplyv je však silnejší na Slovensku, čo ukazuje, prekvapujúco po viac ako polstoročí, na určitú kontinuitu pretrvávajúcich odlišností vývoja identifikovaných už výskumom Československá spoločnost' $\mathrm{z}$ druhej polovice 60 . rokov. Aj vtedy boli pri analýze vzorcov životného štýlu a vol’ného času konštatované rozdiely medzi obomi spoločnost’ami vyplývajúce z ich odlišného stupňa urbanizovanosti a následne i kvalitnejšej infraštruktúrnej vybavenosti českých sídel vyznačujúcich sa rôznorodejšími možnost’ami využívania vol'ného času. V našej analýze sme kládli dôraz nielen na faktory, ktoré majú takpovediac individuálnu povahu, ale aj na faktory, ktoré sú dané spoločnost'ou a jej predchádzajúcim kultúrnym vývojom a ktoré majú nepochybne vplyv nielen na existujúce inštitucionálne prostredie, ale aj na význam rodinného pôvodu, socializácie a kultúrneho kapitálu. Sú to teda nielen existujúce príležitosti, ktoré ovplyvňujú zapájanie do vol'nočasových činností a aktivít vyššej kultúry či aktívneho športu, ale napríklad aj príslušnost' k určitej vekovej kohorte, ktorej významná čast' mohla byt' (a v prípade Slovenska a Česka v určitom období aj bola) socializovaná generáciou vyznačujúcou sa odlišnými kultúrnymi a vzdelanostnými charakteristikami.

Naša štúdia nepochybne otvára niektoré nové otázky. Určite by si komplexnejší prístup zaslúžila problematika priestorovej podmienenosti trávenia vol’ného času, čiže geografickej štruktúry príležitostí viazaných na lokality a mikroregióny. Navrhujeme preto, aby sa d’alší (nielen) komparatívny výskum trávenia vol'ného času venoval regionálnym a vnútroregionálnym rozdielom. Inou otázkou je komparatívna analýza premeny faktorov ovplyvňujúcich trávenie vol'ného času $\mathrm{v}$ časovej perspektíve. Ideálnym prístupom by bola analýza oddel'ujúca efekty veku (životnej fázy) a kohortnej príslušnosti vo väzbe na historické obdobie, čo by umožnilo odpovedat' na otázky ohl'adom generačných premien. Pokial' ide o porovnanie Česka a Slovenska, tak tu sú možnosti značne obmedzené. Ak vôbec existujú porovnatel'né reprezentatívne dáta, tak vd’aka tomu, že sme až donedávna nedisponovali špecializovanými výskumami trávenia vol’ného času, dostupné dáta z predchádzajúcich výskumov (vrátane medzinárodných projektov) väčšinou nezahŕňajú dostatočnú šírku indikátorov vol'nočasových aktivít, a to predovšetkým tých, s ktorými 
prichádzajú do kontaktu mladí l’udia ako inovátori kultúrneho vkusu a s ktorými by bolo možné odhalit' generačne podmienené premeny foriem trávenia vol'ného času a s tým súvisiacich obsahov kultúrneho kapitálu.

Ivan Chorvát pôsobi ako docent na Katedre sociálnych štúdii a etnológie Filozofickej fakulty Univerzity Mateja Bela v Banskej Bystrici, prednáša i na Katedre sociológie Filozofickej fakulty Trnavskej univerzity v Trnave. Venuje sa sociológii rodiny, turizmu, volného času, spotreby a životného štýlu. Je autorom knižných publikácii Muž - otec v súčasnej rodine (1999), Cestovanie a turizmus v zrkadle času (2007), Všedné a sviatočné (2015), Fenomén spotreby a konzumná spoločnost' (2015) a spoluautorom kníh Vol'nočasové aktivity obyvatel'ov Slovenska: poznatky z aktuálnych výskumov (editor, 2011) a Rodina na Slovensku v teórii a vo výskume (spolueditor, 2015). S Jiřím Šafrom editoval monografiu Volný čas, společnost, kultura: Česko - Slovensko (Praha: Sociologické nakladatelství, 2019).

Jiř́ Šafr pracuje ako vedecký pracovnik na oddeleni Sociálnej stratifikácie Sociologického ústavu $A V \breve{C R}$, v. v. i.. Zaoberá sa výskumom sociálnych nerovností a stratifikácie. Zameriava sa hlavne na problematiku sociálnej mobility a kultúrnej reprodukcie, vzniku a účinkov kultúrneho a sociálneho kapitálu. Je autorom monografii Životni styl a sociálni tř́dy: vytváření symbolické kulturni hranice diferenciaci vkusu a spotřeby (2008) a Mechanismy mezigeneračni reprodukce nerovností (spolu s d'alšimi autormi, 2012). S Ivanom Chorvátom editoval monografiu Volný čas, společnost, kultura: Česko - Slovensko (Praha: Sociologické nakladatelství, 2019).

\section{LITERATÚRA}

BIRKELUND, G. E. - LEMEL, Y., 2013: Lifestyles and Social Stratification: An Explorative Study of France and Norway. Comparative Social Research 30, s. 189220. https://doi.org/10.1108/S0195-6310(2013)0000030011

BOURDIEU, P., 1984: Distinction. London and New York: Routledge.

BUNČÁK, J. - HRABOVSKÁ, A. - SOPÓCI, J., 2019: Spôsob života a kultúrna spotreba sociálnych tried $\mathrm{V}$ slovenskej spoločnosti. Sociológia 51(1): 25-43. https://doi.org/10.31577/sociologia.2019.51.5.21

CHAN, T. W. (ed.), 2010: Social Status and Cultural Consumption. Cambridge: Cambridge University Press.

COULANGEON, P., 2005: Educational Attainment and Participation in 'Highbrow Culture'. A comparative Approach in European Union. Paris: Observatoire Sociologique du Changement, OSC, Sciences-Po.

COULANGEON, P. - ROHARIK, I., 2005: Testing the 'Omnivore/Univore' Hypothesis in a Cross-National Perspective. On the Social Meaning of Eclecticism in Musical Tastes in Eight European Countries. Paris: Observatoire Sociologique du Changement, OSC, Sciences-Po. 
DUMAZEDIER J. 1966: Volný čas. Sociologický časopis 2(3): 443-447.

DŽUPINOVÁ, E. - HALÁS, M. - HORŇÁK, M. a kol., 2008: Periférnost' a priestorová polarizácia na území Slovenska. Bratislava: Geografika.

FALK, M. - KATZ-GERRO, T., 2016: Cultural Participation in Europe: Can we Identify Common Determinants? Journal of Cultural Economics 40(2): 127-162. https://doi.org/10.1007/s10824-015-9242-9

GAJDOŠ, P., 2015: Ako sa mení vidiek na Slovensku. Bratislava: Sociologický ústav SAV.

GAJDOŠ, P. - MORAVANSKÁ, K., 2011: Suburbanizácia a jej podoby na Slovensku. Bratislava: VEDA.

GAJDOŠ, P. - PAŠIAK, J., 1995: Vývoj sociálno-ekologickej situácie slovenskej spoločnosti. Bratislava: VEDA.

GRUENBERG, B., 1983: The Social Location of Leisure Styles. American Behavioral Scientist 26(4): 493-508. https://doi.org/10.1177/000276483026004006

HALÁS, M., 2008: Priestorová polarizácia spoločnosti s detailným pohl'adom na periférne regióny Slovenska. Sociologický časopis/Czech Sociological Review 44(2): 349-370. https://doi.org/10.13060/00380288.2008.44.2.06

CHORVÁT, I., 2019a: Máme čas na vol’ný čas? In: Chorvát, I. - Šafr, J. (eds.): Volný čas, společnost, kultura: Česko - Slovensko. Praha: Sociologické nakladatelství, s. 17-37.

CHORVÁT, I., 2019b: Východiská porovnávacej štúdie: česká a slovenská spoločnost'. In: Chorvát, I. - Šafr, J. (eds.): Volný čas, společnost, kultura: Česko - Slovensko. Praha: Sociologické nakladatelství, s. 38-64.

CHORVÁT, I. (ed.), 2011: Vol'nočasové aktivity obyvatel'ov Slovenska. Bratislava: Sociologický ústav SAV.

CHORVÁT, I. - ŠAFR, J. (eds.), 2019: Volný čas, společnost, kultura: Česko Slovensko. Praha: Sociologické nakladatelství.

CHORVÁT, I. - ŠAFR, J., 2019: Vol’ný čas v Česku a na Slovensku v zrkadle troch desat'ročí. In Chorvát, I. - Šafr, J. (eds.): Volný čas, společnost, kultura: Česko Slovensko. Praha: Sociologické nakladatelství, s. 90-132.

KATZ-GERRO, T., 2002: Highbrow Cultural Consumption and Class Distinction in Italy, Israel, West Germany, Sweden, and the United States. Social Forces 81(1): 207-229. https://doi.org/10.1353/sof.2002.0050

KATZ-GERRO, T., 2006: Comparative Evidence of Inequality in Cultural Preferences: Gender, Class, and Family Status. Sociological Spectrum 26(1): 63-83. https://doi.org/10.1080/02732170500368701

LEMEL, Y. - KATZ-GERRO, T., 2015: The Stratification of Leisure: Variation in the Salience of Socioeconomic Dimensions in Shaping Leisure Participationin Two Consumer Societies. Loisir et Société/Society and Leisure 38(3): 399-422. https://doi.org/10.1080/07053436.2015.1083761

LINHART, J., 1969: Úloha životního stylu a spotřeby při vytváření sociální stratifikace. In: Machonin P. a kol.: Československá společnost. Sociologická analýza sociální stratifikace. Bratislava: Epocha, s. 211-234.

MUSIL, J., 1993: Česká a slovenská společnost. Skica srovnávací studie. Sociologický časopis 29(1): 9-24. 
MUSIL, J. - MÜLLER, J., 2008: Vnitřní periferie v České republice jako mechanismus sociální exkluze. Sociologický časopis/Czech Sociological Review 44(2): 321-348. https://doi.org/10.13060/00380288.2008.44.2.05

PATOČKOVÁ, V. - ŠPAČEK, O. - ŠAFR, J., 2012: Mezigenerační „reprodukce“ životního stylu: vliv socializace na trávení volného času v dospělosti. In: Šafr J. a kol.: Mechanismy mezigenerační reprodukce nerovností. Praha: Sociologický ústav Akademie věd ČR, s. 114-131.

RADIČOVÁ, I., 1989: O zemitosti nášho vol'ného času. Sociológia 21(4): 439-446.

ROŠKO, R. - PODOLÁKOVÁ, K. - JANČOVIČOVÁ, J., 1969: Sociálna štruktúra slovenskej a českej spoločnosti (pokus o komparáciu). In: Machonin P. a kol.: Československá společnost. Sociologická analýza sociální stratifikace. Bratislava: Epocha, s. 485-234.

Statistická ročenka České republiky 2016. Praha: Český statistický úřad.

ŠAFR, J., 2012: Životní styl po roce 1989. In: Patočková, V. a kol.: Kultura v krajích České republiky. Praha: Sociologický ústav Akademie věd ČR, s. 231-265.

ŠAFR, J., 2008: Životní styl a sociální třídy: vytváření symbolické kulturní hranice diferenciací vkusu a spotřeby. Praha: Sociologický ústav AV ČR.

ŠAFR J., - PATOČKOVÁ, V., 2010: Trávení volného času v ČR ve srovnání s evropskými zeměmi. Naše společnost 8, č. 2, s. 21-27.

Štatistická ročenka Slovenskej republiky 2015. Bratislava: VEDA.

TAYLOR, M., 2016: Nonparticipation or Different Styles of Participation? Alternative Interpretations from Taking Part. Cultural Trends 25(3): 169-181. https://doi.org/10.1080/09548963.2016.1204051

\section{DÁTOVÉ A INTERNETOVÉ ZDROJE}

ČSÚ 2003. Rozmístění a koncentrace obyvatelstva ČR - 2001. Dostupné z: <https://www.czso.cz/csu/czso/4120-03-casova_rada_1961_20013_velikostni_struktura_obci_>.

Eurostat 2016. Correspondence table. Degree of Urbanisation (DEGURBA) Local Administrative Units. Dostupné z:

$<$ https://ec.europa.eu/eurostat/ramon/miscel laneous/index.cfm?TargetUrl=DSP_DEGURBA>.

Kultura v regionech České republiky 2011 (ČR 2011). Praha: Český sociálněvědní datový archiv. Sociologický ústav AV ČR (CSDA00146).

NOC. 2017. Správa o štátnom štatistickom zistovaní v oblasti kultúry 2016. Bratislava: Národné osvetové centrum (odbor výskumu a štatistiky kultúry). [online]. Dostupné z: <www.culture.gov.sk/extdoc/7866/ sprava_SSZ_2016>.

Sčítanie obyvatel'ov, domov a bytov 2011. Dostupné z: <https://slovak.statistics.sk/ wps/portal/ext/Databases/datacube/!ut/p/z0/04_Sj9CPykssy0xPLMnMz0vMAfI jo8ziw3wCLJycDB0NLEw9TA0cnZ0CTUJ9DIxMfAz1C7IdFQHnSkqO/>.

Sčítání lidu, domů a bytů 2011. Dostupné z: <https://www.czso.cz/csu/czso/scitani-lidu-domu-a-bytu-2011>

Sociológia 53, 2021, č. 2 
Vol'ný čas a sociálna štruktúra na Slovensku 2016 (SR 2016). Omnibusový výskum agentúry FOCUS realizovaný v septembri 2016 pre Katedru sociálnych štúdií a etnológie FF UMB v Banskej Bystrici.

Volný čas a kultura ČR 2011, SR 2016, spojený harmonizovaný dátový súbor. Praha: Český sociálněvědní datový archiv. Sociologický ústav AV ČR. 


\section{Príloha}

Tabul'ka č. A1: Procrustean analysis, koordináty z PCF za SR a ČR a transformácie koordinátov ČR na pozíciu SR, SR 2016, ČR 2011

\begin{tabular}{|c|c|c|c|c|c|c|c|c|c|}
\hline & SR f1 & CR f1 & SR f2 & $\mathrm{CR}$ f2 & SR f3 & CR f3 & Fitted 1 & Fitted 2 & $\mathrm{Q}$ \\
\hline Č́tanie literatúry & 0,783 & 0,542 & $-0,278$ & $-0,302$ & 0,210 & 0,185 & 0,656 & $-0,266$ & 0,014 \\
\hline $\begin{array}{l}\text { Sebavzdelávanie } \\
\text { (jazyky, kurzy) }\end{array}$ & 0,850 & 0,701 & $-0,086$ & $-0,068$ & 0,077 & $-0,103$ & 0,710 & $-0,101$ & 0,001 \\
\hline $\begin{array}{l}\text { Divadlá, koncerty } \\
\text { vážnej hudby, } \\
\text { výstavy }\end{array}$ & 0,811 & 0,714 & $-0,074$ & $-0,038$ & 0,063 & 0,147 & 0,675 & $-0,088$ & 0,004 \\
\hline Pasívny odpočinok & $-0,177$ & $-0,226$ & 0,317 & 0,262 & 0,268 & 0,199 & $-0,207$ & 0,307 & 0,002 \\
\hline Sledovanie TV & $-0,322$ & $-0,289$ & 0,111 & 0,178 & 0,151 & 0,306 & $-0,329$ & 0,133 & 0,004 \\
\hline Počúvanie hudby & 0,481 & 0,363 & 0,362 & 0,213 & $-0,142$ & $-0,258$ & 0,372 & 0,312 & 0,010 \\
\hline $\begin{array}{l}\text { Sledovanie filmov } \\
\text { (DVD, video, PC) }\end{array}$ & 0,492 & 0,261 & 0,386 & 0,347 & $-0,218$ & $-0,280$ & 0,380 & 0,333 & 0,014 \\
\hline $\begin{array}{l}\text { Zábava na PC, } \\
\text { internete }\end{array}$ & 0,457 & 0,334 & 0,403 & 0,299 & $-0,267$ & $-0,286$ & 0,350 & 0,350 & 0,003 \\
\hline $\begin{array}{l}\text { Pohostinské } \\
\text { zariadenia ('na pivo') }\end{array}$ & $-0,103$ & $-0,195$ & 0,724 & 0,793 & $-0,053$ & $-0,026$ & $-0,153$ & 0,661 & 0,019 \\
\hline $\begin{array}{l}\text { Kaviarne, vinárne, } \\
\text { reštaurácie }\end{array}$ & 0,333 & 0,095 & 0,634 & 0,735 & $-0,150$ & 0,026 & 0,233 & 0,559 & 0,050 \\
\hline $\begin{array}{l}\text { Diskotéky, tanečné } \\
\text { akcie }\end{array}$ & 0,416 & 0,277 & 0,494 & 0,493 & $-0,310$ & $-0,260$ & 0,311 & 0,432 & 0,005 \\
\hline $\begin{array}{l}\text { Stretávanie s pria- } \\
\text { tel'mi, známymi }\end{array}$ & $-0,019$ & 0,080 & 0,684 & 0,524 & 0,219 & 0,198 & $-0,079$ & 0,622 & 0,035 \\
\hline Športové diváctvo & 0,305 & 0,185 & 0,462 & 0,507 & $-0,032$ & $-0,001$ & 0,213 & 0,410 & 0,010 \\
\hline $\begin{array}{l}\text { Stretávanie s prí- } \\
\text { buznými }\end{array}$ & 0,111 & 0,147 & 0,336 & 0,186 & 0,367 & 0,352 & 0,046 & 0,309 & 0,025 \\
\hline $\begin{array}{l}\text { Manuálne práce } \\
\text { (šitie, 'kutilstvo') }\end{array}$ & 0,076 & 0,182 & 0,012 & $-0,078$ & 0,645 & 0,359 & 0,025 & 0,025 & 0,035 \\
\hline $\begin{array}{l}\text { Prechádzky, výlety } \\
\text { do prírody }\end{array}$ & 0,480 & 0,429 & 0,154 & 0,003 & 0,350 & 0,374 & 0,377 & 0,130 & 0,019 \\
\hline $\begin{array}{l}\text { Chodenie po } \\
\text { obchodoch, nákup. } \\
\text { centrách }\end{array}$ & 0,354 & 0,294 & 0,176 & 0,118 & 0,093 & 0,214 & 0,265 & 0,155 & 0,002 \\
\hline Starostlivost' o seba & 0,670 & 0,635 & 0,127 & 0,109 & 0,025 & $-0,016$ & 0,545 & 0,096 & 0,008 \\
\hline $\begin{array}{l}\text { Športovanie, } \\
\text { cvičenie }\end{array}$ & 0,677 & 0,605 & 0,240 & 0,111 & $-0,062$ & $-0,099$ & 0,548 & 0,195 & 0,010 \\
\hline Kiná, multikiná & 0,645 & 0,520 & 0,240 & 0,278 & $-0,293$ & $-0,189$ & 0,520 & 0,197 & 0,007 \\
\hline Noviny (čítanie) & 0,281 & 0,080 & 0,117 & 0,160 & 0,253 & 0,206 & 0,202 & 0,107 & 0,018 \\
\hline $\begin{array}{l}\text { Práca na záhrade; } \\
\text { údržba domu, auta }\end{array}$ & 0,007 & $-0,107$ & $-0,133$ & $-0,049$ & 0,615 & 0,345 & $-0,032$ & $-0,099$ & 0,008 \\
\hline
\end{tabular}

Poznámka: fitted - hodnoty predikované modelom pre ČR po transformácii na konfiguráciu SR; Q - súčet štvorcov reziduálov (RSS) jednotlivých ciel'ových premenných za ČR

Zdroj: Volný čas a kultura ČR 2011, SR 2016 